\title{
Phytoplankton and bacterial uptake of inorganic and organic nitrogen during an induced bloom of Phaeocystis pouchetii
}

\author{
M. P. Sanderson ${ }^{1, *}$, D. A. Bronk ${ }^{1}$, J. C. Nejstgaard ${ }^{2}$, P. G. Verity ${ }^{3}$, A. F. Sazhin ${ }^{4}$, \\ M. E. Frischer ${ }^{3}$ \\ ${ }^{1}$ Virginia Institute of Marine Science, College of William and Mary, PO Box 1346, Gloucester Point, Virginia 23062, USA \\ ${ }^{2}$ Department of Biology, UNIFOB, University of Bergen, PO Box 7800, Bergen 5020, Norway \\ ${ }^{3}$ Skidaway Institute of Oceanography, 10 Ocean Science Circle, Savannah, Georgia 31411, USA \\ ${ }^{4}$ P.P. Shirshov Institute of Oceanology RAS, 36 Nakhimovsky Prospect, Moscow 117851, Russia
}

\begin{abstract}
A mesocosm experiment was conducted during the spring of 2003 in Raunefjord, west Norway. Inorganic nutrients $\left(16 \mu \mathrm{mol} \mathrm{l}^{-1}\right.$ nitrate, $1 \mu \mathrm{mol} \mathrm{l^{-1 }}$ phosphate) were added to 2 enclosures with $10 \%$ of those concentrations $\left(1.6 \mu \mathrm{mol} \mathrm{l}^{-1}\right.$ nitrate, $0.1 \mu \mathrm{mol} \mathrm{l} \mathrm{l}^{-1}$ phosphate) added daily thereafter; a third unamended mesocosm was used as a control. Nitrogen (N) (ammonium, nitrate, urea and amino acid) uptake rates for $>0.8 \mu \mathrm{m}$ (largely composed of phytoplankton) and 0.2 to $0.8 \mu \mathrm{m}$ (largely composed of bacteria) size classes were measured, as well as nutrient, chlorophyll, phytoplankton and microzooplankton concentrations. The nutrient additions initiated a process resulting in a large bloom of Phaeocystis pouchetii colonies. There was a $2.5 \mathrm{wk}$ lag, during which a smaller bloom of phototrophic flagellates, followed by diatoms, formed in all mesocosms; diatoms increased until silicic acid was depleted. After the flagellate and diatom bloom dissipated, the mesocosms were depleted of inorganic N. Dissolved organic N (DON) remained constant in all mesocosms during the flagellate and diatom bloom but increased with the onset of the large $P$. pouchetii bloom, largely due to release of urea and amino acids, which made up $>93 \%$ of the DON pool at the end of the experiment. Uptake rates of urea often accounted for the largest percentage of total $\mathrm{N}$ uptake in all mesocosms for both the $>0.8 \mu \mathrm{m}$ and 0.2 to $0.8 \mu \mathrm{m}$ size classes, generally providing the largest percentage (up to $88 \%$ ) of bacterial $\mathrm{N}$ demand of any substrate. This was particularly true during the Phaeocystis bloom when urea uptake rates were up to 65 times greater than the other $\mathrm{N}$ substrates. We observed a switch from new production, when nitrate uptake dominated during the diatom bloom, to regenerated production during the Phaeocystis bloom. The present study adds to the growing body of evidence that organic $\mathrm{N}$ is a substantial source of $\mathrm{N}$ for both phytoplankton and bacteria.
\end{abstract}

KEY WORDS: Nitrogen uptake $\cdot$ Mesocosm experiments $\cdot$ Phaeocystis $\cdot$ Diatoms $\cdot$ Bacteria

\section{INTRODUCTION}

Liebig's Law of the Minimum (Liebig 1840) states that the overall production in an area will be determined by the availability of the nutrient that is needed for growth and is present in the lowest concentration relative to its demand. In many marine ecosystems the macronutrient nitrogen $(\mathrm{N})$ limits biological production. Dissolved inorganic N (DIN) compounds, ammo- nium $\left(\mathrm{NH}_{4}{ }^{+}\right)$, nitrate $\left(\mathrm{NO}_{3}^{-}\right)$and nitrite $\left(\mathrm{NO}_{2}{ }^{-}\right)$, were originally considered the main bioavailable $\mathrm{N}$ compounds; however, it has been shown that dissolved organic N (DON) forms, such as urea (e.g. Lomas et al. 2002), amino acids (e.g. Fuhrman 1990) and even humics (See et al. 2006), can also contribute to planktonic N nutrition (reviewed in Berman \& Bronk 2003).

The importance of DIN for the nutrition and growth of marine phytoplankton has long been recognized 
(e.g. Dugdale \& Goering 1967), whereas DIN utilization by bacteria has received less attention. In contrast, DON has been considered to be more important for the nutrition and growth of heterotrophic organisms than for phytoplankton. Competition between phytoplankton and bacteria for available $\mathrm{N}$ has been an active area of research (e.g. Lancelot \& Billen 1984, Lancelot \& Mathot 1987, Veuger et al. 2004). In general, the small size and resulting high surface to volume ratio of bacteria make them superior competitors.

In the fjords of Norway, phytoplankton blooms occur in early spring as light increases and the nutrient-rich water from winter mixing stratifies within the euphotic zone (Erga \& Heimdal 1984). In northern latitudes, blooms of the colony-forming prymnesiophyte Phaeocystis pouchetii have been reported simultaneously with or immediately following spring blooms of chainforming diatoms between February and May, but may also occur in high numbers during the fall (e.g. Heimdal 1974). P. pouchetii can be found as single cells or cells embedded in a gelatinous colony. As blooms progress, the number of small individual cells typically decreases coincident with the appearance of more colonies. Finally, as a bloom declines and colonies senesce, bacterial communities are likely involved in the decomposition and remineralization of colony materials. It has been widely reported that bacterial biomass and activity increase following Phaeocystis spp. blooms (e.g. Fernández et al. 1992, Nejstgaard et al. 2006).

Large blooms of Phaeocystis pouchetii colonies are significant because they can increase export of material to the deep ocean via the biological pump (Verity \& Medlin 2003) and can produce large quantities of dimethyl sulfide, which act as cloud condensation nuclei resulting in a climate-cooling effect due to cloud formation (Charlson et al. 1987). They are also classified as a harmful algal bloom (HAB) species because they are known to produce toxins which are lethal to fish larvae (Eilertsen \& Raa 1995). These dense blooms may also affect higher trophic levels, leading to negative influences on human activities such as fisheries (net clogging and fish mortality), fish farming (altering fish taste) and tourism (odorous foams of a declining/ decaying bloom on coastal beaches, Schoemann et al. 2005 and references therein).

Phaeocystis pouchetii often dominates over diatoms in waters with low silicic acid $\left(\mathrm{H}_{2} \mathrm{SiO}_{3}\right)$ concentrations $\left(<2 \mu \mathrm{mol} \mathrm{l} l^{-1}\right)$ and surplus $\mathrm{NO}_{3}^{-}\left(>5 \mu \mathrm{mol} \mathrm{l}^{-1}\right)$ and phosphate $\left(\mathrm{PO}_{4}{ }^{3-},>0.2 \mu \mathrm{mol} \mathrm{l}{ }^{-1}\right.$ ) (e.g. Egge \& Jacobsen 1997). However, $\mathrm{H}_{2} \mathrm{SiO}_{3}$ availability is not a unique predictor of $P$. pouchetii versus diatom dominance (e.g. Larsen et al. 2004). Blooms of $P$. pouchetii typically comprise the colonial form, although there are a few reports of blooms of solitary $P$. pouchetii cells (Wassmann et al. 2005). Colony formation could be a means to escape predation (Fernández et al. 1992), to control buoyancy in order to keep cells in the upper layers of the euphotic zone (Skreslet 1988) or to avoid viral infection (e.g. Bratbak et al. 1998). A fundamental mechanistic understanding of all the factors that contribute to the formation of $P$. pouchetii blooms and colony formation, however, remains elusive (Larsen et al. 2004, Schoemann et al. 2005, Nejstgaard et al. 2006). Nevertheless, many mesocosm studies have shown that a bloom of $P$. pouchetii can be initiated by the addition of both $\mathrm{N}$ and phosphorus (P) during the early spring (Egge \& Heimdal 1994 and references therein).

The present study was conducted as part of a larger mesocosm project designed to investigate the onset of colony formation in Phaeocystis pouchetii while mimicking the formation of a typical bloom in Raunefjord, Norway (Nejstgaard et al. 2006, Verity et al. 2007b). The use of mesocosm enclosures allows for an experiment of larger spatial and temporal scales without complicating issues typically seen in smaller scale experiments or in situ field studies. Mesocosm enclosures contain large volumes of water and therefore allow multiple investigators to conduct experiments simultaneously without sacrificing experimental integrity due to insufficient sample volumes. Furthermore, bottle effects are essentially eliminated due to the large sample size, and the experiments are more representative of processes that occur in nature due to maintenance of realistic temperature and irradiance levels and the inclusion of higher trophic levels of natural plankton assemblages, including grazers that are often excluded from bottle experiments. An added benefit of mesocosm studies is that one does not have the difficulty of following a given water mass (i.e. drogue studies), and the experiment can continue for a longer period of time without complications arising from advection of surrounding water masses.

In the present study, experiments were conducted during the early spring of 2003 in Raunefjord, Norway, in mesocosms amended with $\mathrm{NO}_{3}{ }^{-}$and $\mathrm{PO}_{4}{ }^{3-}$ and monitored for $34 \mathrm{~d}$. The present study focuses on the utilization of nutrients, succession of phytoplankton species and the uptake of both inorganic and organic $\mathrm{N}$ compounds in phytoplankton $(>0.8 \mu \mathrm{m})$ and bacterial ( 0.2 to $0.8 \mu \mathrm{m}$ ) size classes during the onset and decline of a Phaeocystis pouchetii bloom. We hypothesized that inorganic $\mathrm{N}$ would be relatively more important early in the experiment and that the reliance on organic $\mathrm{N}$ would increase as the $P$. pouchetii bloom developed and declined. We also hypothesized that rates of bacterial uptake would be lower than phytoplankton uptake and would increase with the decline of the $P$. pouchetii bloom. Experimental results indicate that both hypotheses were true. 


\section{MATERIALS AND METHODS}

Experimental design. Mesocosm studies were conducted at The University of Bergen's Marine Biological Field Station in Espegrend, Norway (www.bio.uib.no/ pages/mbs.php). Experiments were conducted over a $34 \mathrm{~d}$ period from 28 February to 2 April 2003. Three mesocosm enclosures were attached to a floating dock $200 \mathrm{~m}$ offshore in Raunefjord. The enclosures were $2 \mathrm{~m}$ in diameter, $4.5 \mathrm{~m}$ deep and contained $11 \mathrm{~m}^{3}$ of water. The bags, made of a transparent polyethylene material, were open at the top and designed to allow ca. $90 \%$ penetration of photosynthetically active radiation. The water within each enclosure was kept well mixed using an airlift system that pumped ca. 401 water min $^{-1}$ (Nejstgaard et al. 2006). All enclosures had 10\% of their water renewed daily with adjacent fjord water to allow for the introduction of new species, to avoid substantial $\mathrm{pH}$ changes due to primary production and to replace water removed for analyses (see Williams \& Egge 1998 for more information on water renewal).

All enclosures were filled with unfiltered fjord water from a depth of $5 \mathrm{~m}$ on 28 February 2003. One of the enclosures (M1) was treated as a control and the other two were amended with nutrients (M2 and M3). The 2 nutrient-amended mesocosms had $16 \mu \mathrm{mol} \mathrm{l^{-1 }} \mathrm{NO}_{3}{ }^{-}$ and $1 \mathrm{\mu mol} \mathrm{l}^{-1} \mathrm{PO}_{4}{ }^{3-}$ added initially in the forms of $\mathrm{NaNO}_{3}$ and $\mathrm{KH}_{2} \mathrm{PO}_{4}$, respectively, and then $10 \%$ (or $1.6 \mu \mathrm{mol} \mathrm{l} \mathrm{l}^{-1} \mathrm{NO}_{3}{ }^{-}$and $0.1 \mathrm{mmol} \mathrm{l}^{-1} \mathrm{PO}_{4}{ }^{3-}$ ) of the nutrients added daily thereafter at noon to replace nutrients lost by the daily $10 \%$ water exchange. Amendments to M2 were stopped on Day 19 to initiate decline of the bloom in that enclosure; additions to M3 continued daily throughout the experiment. Mesocosms were sampled between 08:00 and 09:00 h daily for chlorophyll a ( $\mathrm{chl} a$ ) and approximately every $3 \mathrm{~d}$ for nutrient, phytoplankton and microzooplankton concentrations, as well as $\mathrm{N}$ uptake rates; for further details of the experimental design see Nejstgaard et al. (2006).

Biomass and nutrient measurements. Concentrations of chl $a$ and particulate $\mathrm{N}(\mathrm{PN})$ were measured as proxies for biomass. Concentrations of chl a were measured fluorometrically on a Turner Design Model 10AU fluorometer; samples were filtered onto Sartorius filters (25 mm diameter, $0.45 \mu \mathrm{m}$ pore size), extracted in $90 \%$ acetone at $4^{\circ} \mathrm{C}$ overnight and analyzed according to Parsons et al. (1984). Concentrations of PN were measured at the end of incubation during the analysis of mass spectrometer samples as described below.

Phytoplankton and microzooplankton cells were identified and enumerated by epifluorescence microscopy. Plankton $<10 \mu \mathrm{m}$ were analyzed in triplicate samples $(15 \mathrm{ml})$ that were prepared by gently passing water through a $10 \mu \mathrm{m}$ nylon mesh. Each sample was fixed with HPLC-grade glutaraldehyde $(0.5 \%$ final concentration), stained with proflavin (100 $\mathrm{ng} \mathrm{ml}^{-1}$ final concentration) and DAPI (25 ng ml-1 final concentration) as described by Porter \& Feig (1980), with the exception that higher concentrations of stain were required to effectively stain Phaeocystis pouchetii cells. Epifluorescent slides were made by gently filtering the fixed and stained samples onto black $0.2 \mu \mathrm{m}$ $25 \mathrm{~mm}$ diameter polycarbonate filters using a hand pump with $<0.5 \mathrm{~mm} \mathrm{Hg}$ vacuum pressure. Filters were mounted onto glass slides with a cover slip and stored at $-20^{\circ} \mathrm{C}$ until analyzed. Cells were visualized by epifluorescence microscopy using an Olympus BX-60 fluorescence microscope equipped with a $60 \times$ Planapo NA 1.40 oil objective. For each slide a minimum of 20 fields or 300 cells were examined. Plankton $>10 \mu \mathrm{m}$ were enumerated in $60 \mathrm{ml}$ of whole water that was treated with EDTA (10 mmol $\mathrm{l}^{-1}$ final concentration) before fixing, staining and storing as above. The EDTA was added to disperse $P$. pouchetii colonies without affecting cell morphology or total cell abundance (Nejstgaard et al. 2006). Flagellated P. pouchetii solitary cells and other small cells were enumerated in the $<10 \mu \mathrm{m}$ samples. Microflagellates (autotrophic, heterotrophic and mixotrophic), diatoms and total $P$. pouchetii cells (solitary and colonial) were identified and enumerated in the EDTA-treated samples. Ciliates and large dinoflagellates ( $<50 \mu$ m diameter) were enumerated in the EDTA-treated samples by screening and counting all cells present on the whole slide $(15 \mathrm{ml})$.

Nutrients were monitored in all mesocosms throughout the experiment and analyses were performed in duplicate (urea) or triplicate (all others). Unless otherwise noted all nutrient samples were filtered upon collection and frozen immediately in acid-cleaned bottles until analysis; urea and $\mathrm{NH}_{4}{ }^{+}$samples were stored in polypropylene bottles, and all other nutrients were stored in high-density polyethylene (HDPE) bottles. Concentrations of $\mathrm{NH}_{4}{ }^{+}$were determined colorometrically using the manual phenol hypochlorite technique (detection limit $0.05 \mu \mathrm{mol} \mathrm{N} \mathrm{^{-1 }}$, Koroleff 1983). Concentrations of $\mathrm{NO}_{3}{ }^{-}$and $\mathrm{NO}_{2}^{-}$were measured on an O.I. Analytical Alpkem Flow Solution IV autoanalyzer using the Parsons et al. (1984) colorimetric technique (detection limit 0.003 and $0.002 \mu \mathrm{mol} \mathrm{N} \mathrm{l}^{-1}$, respectively). Urea concentrations were measured manually using the monoxime method (detection limit 0.025 umol $\mathrm{N} \mathrm{l}^{-1}$, Price \& Harrison 1987). Amino acid (AA) concentrations were measured as dissolved primary amines (DPA) using a fluorometric OPA (o-phthal-

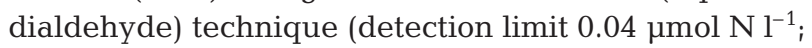
Parsons et al. 1984). In waters with low concentrations of $\mathrm{NH}_{4}{ }^{+}$, measurements of free AA and DPA are approximately equal (Kirchman et al. 1989); therefore we will refer to them as AA. Total dissolved N (TDN) 
was measured using the Valderrama (1981) persulfate oxidation technique as described in Bronk et al. (2000); the oxidized samples were treated like $\mathrm{NO}_{3}{ }^{-}$samples as described above. The concentration of DON was calculated as the difference between TDN and the sum of $\mathrm{NH}_{4}{ }^{+}, \mathrm{NO}_{3}{ }^{-}$and $\mathrm{NO}_{2}{ }^{-}$; the $\mathrm{SD}$ for DON concentration was calculated using a propagation of error analysis (Bronk et al. 2000). Samples $(20 \mathrm{ml})$ for analysis of $\mathrm{PO}_{4}{ }^{3-}$ and $\mathrm{H}_{2} \mathrm{SiO}_{3}$ were fixed with $0.2 \mathrm{ml}$ chloroform and stored at $4{ }^{\circ} \mathrm{C}$ until analysis as described in Nejstgaard et al. (2006). Phosphate data were lost for Days 24 through 28 due to an analytical error associated with the instrument.

Measurements of uptake rates. Nitrogen uptake rates were measured approximately every $3 \mathrm{~d}$ using standard ${ }^{15} \mathrm{~N}$ uptake techniques as described in Bronk et al. (1998). Rates were determined for $\mathrm{NH}_{4}{ }^{+}, \mathrm{NO}_{3}{ }^{-}$, urea and a mixture of AA for 2 size classes: the $>0.8 \mu \mathrm{m}$ fraction and the 0.2 to $0.8 \mu \mathrm{m}$ fraction.

For each rate measurement, $1 \mathrm{l}$ polyethylene terephthalate copolyester (PETG) bottles were filled with mesocosm water and amended with tracer levels, $\leq 10 \%$ of the ambient substrate concentration, of an ${ }^{15} \mathrm{~N}$-labeled substrate (ammonium chloride, $98 \%+{ }^{15} \mathrm{~N}$; potassium nitrate, $98 \%+{ }^{15} \mathrm{~N}$; urea, $99 \%{ }^{13} \mathrm{C}, 98 \%+$ ${ }^{15} \mathrm{~N}_{i}$ or an algal AA mixture, lot \# P-7934, $98 \%+{ }^{13} \mathrm{C}, 96$ to $99 \%{ }^{15} \mathrm{~N}$, all obtained from Cambridge Isotope Laboratories). Bottles were incubated at in situ temperatures and light intensities in the fjord by placing them in mesh bags suspended near the mesocosm enclosures for ca. $3 \mathrm{~h}$. Incubations were performed in duplicate and were ended by filtering $(<150 \mathrm{~mm} \mathrm{Hg}$ vacuum) an aliquot over a $0.8 \mu \mathrm{m}$ silver filter to collect the $>0.8 \mu \mathrm{m}$ size fraction. The filtrate was then passed through a $0.2 \mu \mathrm{m}$ silver filter to obtain the 0.2 to $0.8 \mu \mathrm{m}$ size fraction, representing the bacterial size class. All silver filters were frozen initially and then thawed and dried at $40^{\circ} \mathrm{C}$ in a drying oven overnight prior to simultaneous analysis of PN and particulate carbon concentrations and ${ }^{15} \mathrm{~N}$ and ${ }^{13} \mathrm{C}$ isotopic enrichments. All isotope samples were analyzed on a Europa Automated Nitrogen Carbon Analyzer for Solids and Liquids (ANCA-SL) attached to a GEO 20/20 or 20/20 isotope ratio mass spectrometer. Unfortunately, the replicate samples for the $>0.8 \mu \mathrm{m}$ size fraction for urea and AA uptake were irretrievably lost during an errant run on the mass spectrometer. Uptake rates were calculated using the equations originally described in Dugdale \& Goering (1967). Rates of $\mathrm{NH}_{4}{ }^{+}$uptake were corrected for isotope dilution, and $\mathrm{NH}_{4}{ }^{+}$regenerations rates were determined using the isotope dilution method (Glibert et al. 1982). Ammonium was isolated using solid phase extraction (Dudek et al. 1986). Uptake rates of $\mathrm{NO}_{3}{ }^{-}$ were not corrected for isotope dilution. The elevated $\mathrm{NO}_{2}{ }^{-}$concentrations observed early in the experiment (ca. the first 18 d) suggest that nitrification or $\mathrm{NO}_{2}{ }^{-}$ excretion (Lomas \& Lipschultz 2006) may have been occurring such that isotope dilution of the $\mathrm{NO}_{3}{ }^{-}$tracer could have taken place. However, with the very high concentrations of $\mathrm{NO}_{3}^{-}$present during this time $\left(>14 \mu \mathrm{mol} \mathrm{N}{ }^{-1}\right.$ ), any dilution of isotope due to nitrification or phytoplankton excretion would have had a negligible impact on measured $\mathrm{NO}_{3}^{-}$uptake rates. Urea and AA uptake rates were also not corrected for isotope dilution. There were increases in urea and AA concentrations later in the experiment, indicating urea and AA regeneration; this suggests that uptake rates of these substrates may have been underestimated due to isotope dilution. We note that correcting for isotope dilution in urea and AA incubations would enhance the patterns we observed. No correction was done for loss of $\mathrm{DO}^{15} \mathrm{~N}$ during the incubations; as such, the uptake rates presented are all net rates (Bronk et al. 1994).

Bacterial productivity in whole seawater samples was estimated based on incorporation rates of ${ }^{3} \mathrm{H}$ leucine determined essentially following the protocol of Smith \& Azam (1992), except that to achieve saturated maximal uptake rates, ${ }^{3} \mathrm{H}$-leucine was added to yield $60 \mathrm{nmol} \mathrm{l}^{-1}$ final concentrations. Initial studies using water samples from mesocosm enclosures were conducted to determine optimal ${ }^{3} \mathrm{H}$-leucine concentrations (data not shown). Bacterial productivity was estimated from leucine incorporation rates using conversion factors as described by Kirchman \& Ducklow (1993).

\section{RESULTS}

\section{Biomass and species composition}

Concentrations of chl a increased from 0.5 to $5 \mathrm{\mu g} \mathrm{l}^{-1}$ over the first 2 wk in all mesocosms (Fig. 1a); this moderate increase in chl a will be referred to as the flagellate and diatom bloom. In the $\mathrm{NO}_{3}{ }^{-}$and $\mathrm{PO}_{4}{ }^{3-}$ amended mesocosms (M2 and M3), the chl a concentrations continued to increase from 5 up to $30 \mu \mathrm{g} \mathrm{l}^{-1}$ due to a bloom of Phaeocystis pouchetii. The highest chl a concentrations were observed in $\mathrm{M} 3$, the mesocosm that received continuous $\mathrm{NO}_{3}{ }^{-}$and $\mathrm{PO}_{4}{ }^{3-}$ nutrient additions throughout the experiment. Concentrations of $\mathrm{chl} a$ peaked around Day 25 and then began to decline in M2 and M3, although by Day 34 the concentrations were still higher than those observed in the control mesocosm.

Concentrations of total PN (combined $>0.8 \mu \mathrm{m}$ and 0.2 to $0.8 \mu \mathrm{m}$ fractions) behaved similarly in all 3 mesocosms over the first $2 \mathrm{wk}$ and increased from $1.9 \pm 0.3$ to ca. $6.0 \mu \mathrm{mol} \mathrm{N}{ }^{-1}$ (Fig. 1b). In the control mesocosm, 

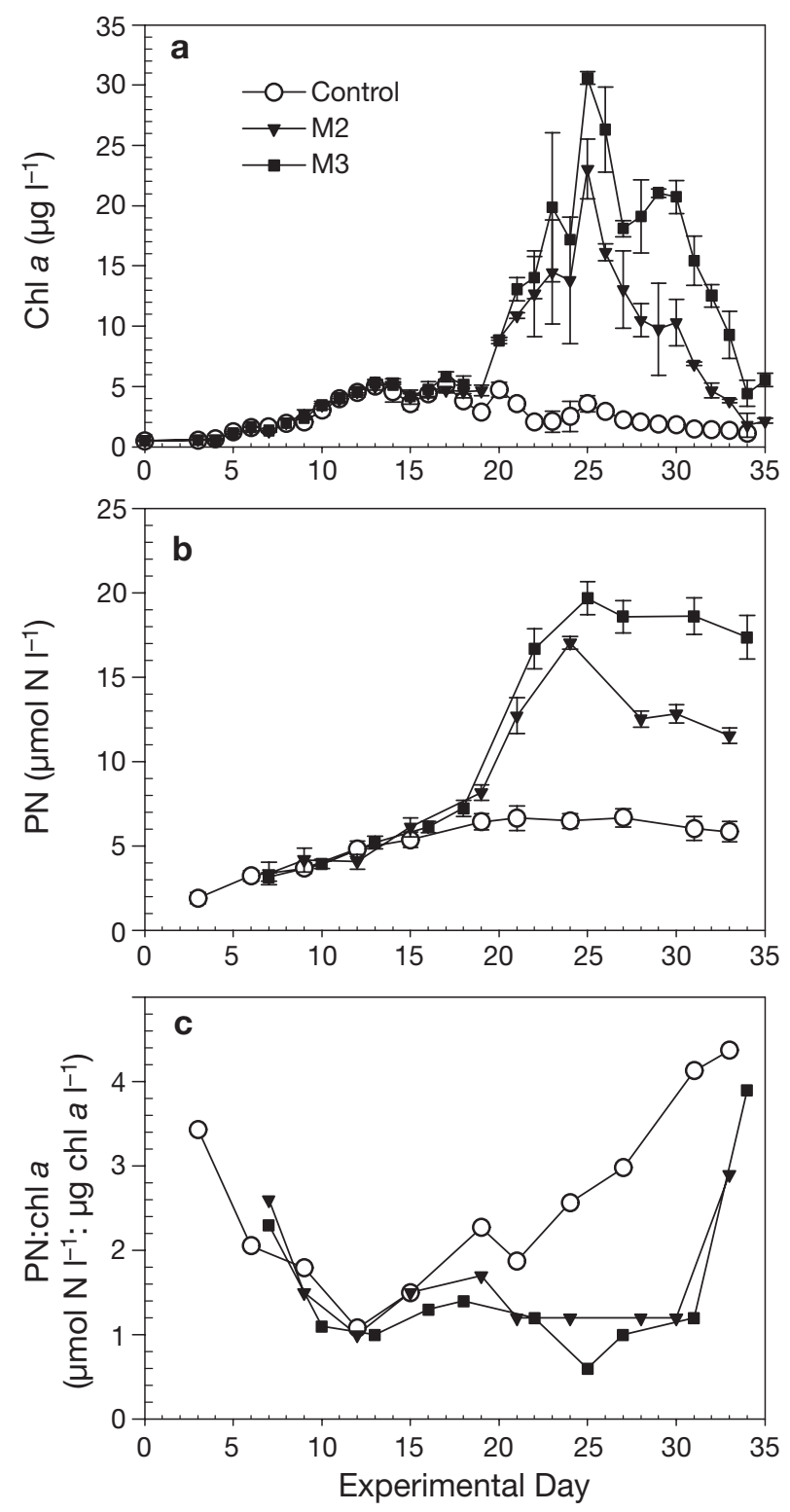

Fig. 1. Concentrations of (a) chlorophyll a (chl a), (b) total particulate nitrogen (PN) and (c) PN:chl $a$, including both the $>0.8 \mu \mathrm{m}$ and 0.2 to $0.8 \mu \mathrm{m}$ size fractions, versus experimental day for the control and the 2 nutrient-amended mesocosms, M2 and M3. Error bars in (a) and (b) represent SD; when they do not appear they are smaller than the symbols

PN concentrations leveled off between 6.0 and

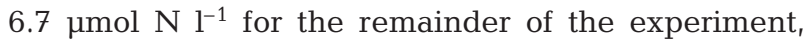
whereas in M2 and M3 PN increased to $17.1 \pm 0.4$ and $19.7 \pm 1.0 \mu \mathrm{mol} \mathrm{N}{ }^{-1}$ by Days 24 and 25, respectively, before declining. The increase in $\mathrm{PN}$ observed in all mesocosms was largely due to the $>0.8 \mu \mathrm{m}$ size fraction. $\mathrm{PN}$ in the 0.2 to $0.8 \mu \mathrm{m}$ size fraction increased slightly in all mesocosms over the entire experiment, starting out at $0.62 \pm 0.29 \mu \mathrm{mol} \mathrm{N} \mathrm{^{-1 }}$ and increasing to $1.62 \pm 0.23 \mu \mathrm{mol} \mathrm{N} \mathrm{^{-1 }}$ in the control and to $2.0 \pm 0.29$

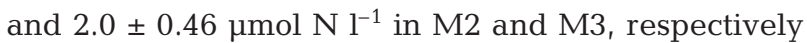
(data not shown).

At the start of the experiment, ratios of $\mathrm{PN}: \mathrm{chl} a$

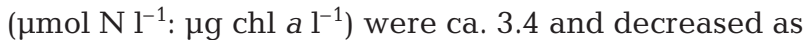
the flagellate and diatom bloom formed to approach 1:1 in all mesocosms within the first $10 \mathrm{~d}$ or so (Fig. 1c). This ratio started to increase in the control as the flagellate and diatom bloom declined and continued increasing throughout the remainder of the experiment, reaching 4.4 by Day 33. In M2 and M3 the ratio increased slightly, but remained between 1.0 and 1.5 during the end of the flagellate and diatom bloom and into the start of the Phaeocystis bloom. However, by the peak of the Phaeocystis pouchetii colony bloom it had decreased to 1.2 and 0.6 for M2 and M3, respectively. These ratios remained close to 1 until the very end of the experiment when the ratio increased to 2.9 in M2 on Day 33 and to 3.9 in M3 on Day 34.

Phytoplankton species composition in all mesocosms was initially dominated by small ( 2 to $5 \mu \mathrm{m}$ ) phototrophic flagellates, other than Phaeocystis pouchetii cells (Fig. 2). There was a small bloom and subsequent decline of diatoms (mainly Chaetoceros socialis and Skeletonema costatum) during the first $2 \mathrm{wk}$ in all mesocosms. The small phototrophic algae also increased in cell numbers initially before decreasing; however, they remained present at a low level throughout the remainder of the experiment. Heterotrophic flagellates and ciliates were present in low numbers at the start of the experiment and increased slightly during the last third of the experiment. The largest change in species numbers occurred in M2 and M3 where large blooms of colonial $P$. pouchetii developed (Fig. 2b,c). Prior to the colonial bloom (Days 1 to 16), P. pouchetii was present largely as solitary cells (see Nejstgaard et al. [2006] for additional community composition data).

\section{Nutrients}

Initial concentrations of TDN were ca. $11 \mu \mathrm{mol} \mathrm{N} \mathrm{l}^{-1}$ (before nutrient addition) and decreased over the first $21 \mathrm{~d}$ of the experiment before leveling off around

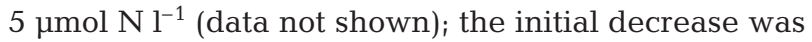
due to the rapid draw-down of inorganic N. At the beginning of the experiment, roughly $65 \%$ of the TDN pool was DIN. During the last $1.5 \mathrm{wk}$ of the experiment, however, $<5 \%$ of the TDN pool was DIN as a result of the increase in DON and substantial DIN uptake.

Initial $\mathrm{NO}_{3}{ }^{-}$concentrations were ca. $6.6 \mu \mathrm{mol} \mathrm{N}{ }^{-1}$. This dropped in the control mesocosm to $0.06 \pm$

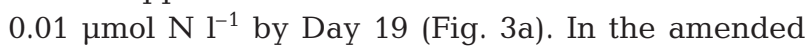

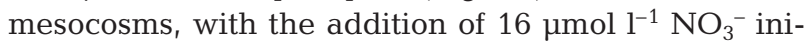



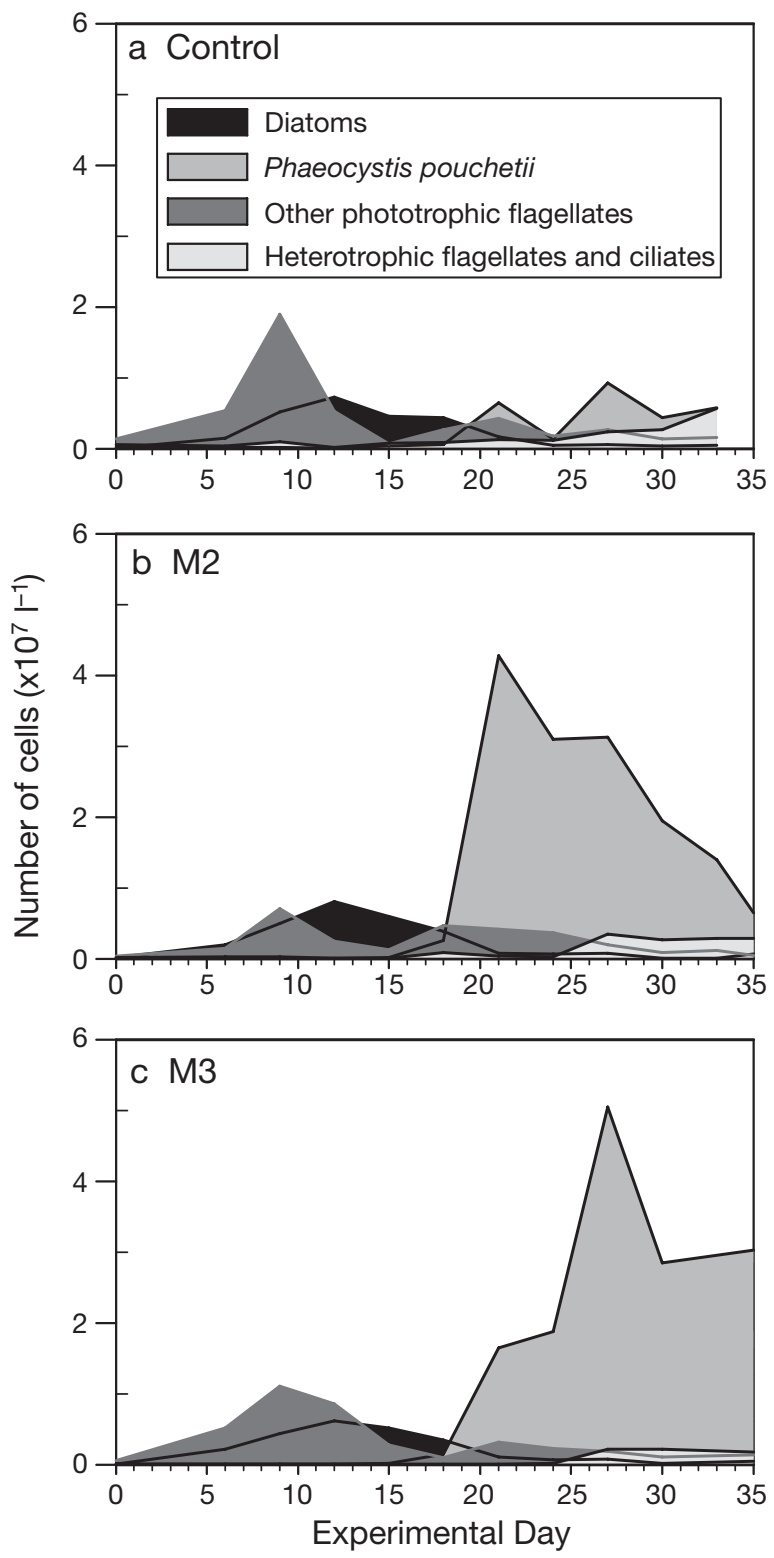

Fig. 2. Species composition in number of cells versus experimental day for (a) control, (b) M2 and (c) M3 mesocosms

tially and $1.6 \mu \mathrm{mol} \mathrm{l}^{-1} \mathrm{NO}_{3}{ }^{-}$daily thereafter (except in M2 where $\mathrm{NO}_{3}{ }^{-}$additions stopped on Day 19 ), the concentration of $\mathrm{NO}_{3}{ }^{-}$had been drawn down to between 0.01 and $0.02 \mu \mathrm{mol} \mathrm{N} \mathrm{^{-1 }}$ by Day 22. Concentrations of $\mathrm{NH}_{4}{ }^{+}$in all 3 mesocosms were rapidly drawn down during the first $5 \mathrm{~d}$ from initial concentrations of ca. $0.4 \mu \mathrm{mol} \mathrm{N} \mathrm{l}{ }^{-1}$ and then remained ca. $0.15 \mu \mathrm{mol} \mathrm{N} \mathrm{l}^{-1}$ for the remainder of the experiment (Fig. 3b), likely reflecting a balance between production and consumption. Concentrations of $\mathrm{NO}_{2}{ }^{-}$remained fairly constant during the first $15 \mathrm{~d}$, then were drawn down from initial concentrations of ca. $0.10 \mu \mathrm{mol} \mathrm{N} \mathrm{l^{-1 }}$ to below detection by Day 19 (control) and by Day 24 (M2 and M3, Fig. 3c).
Concentrations of DON in all 3 mesocosms were stable during the first $10 \mathrm{~d}$ before decreasing slightly around Day 15 and then increasing for the remainder of the experiment (Fig. 3d). The greatest increase in DON concentration was observed in the nutrientamended mesocosms, and the increase was mainly due to increases in urea concentrations (Fig. 3e). At the start of the experiment $>55 \%$ of the DON was undefined, $35 \%$ was urea, and AA comprised the remainder (Fig. 3d-f). As the Phaeocystis pouchetii bloom developed, the percentage of DON due to urea and AA increased to $>80$ and $13 \%$, respectively.

Concentrations of $\mathrm{PO}_{4}{ }^{3-}$ declined slowly in the control throughout the experiment (Fig. 4a). In M2 and $\mathrm{M} 3$, which had $1.0 \mu \mathrm{mol} \mathrm{l}{ }^{-1} \mathrm{PO}_{4}{ }^{3-}$ added initially and $0.1 \mathrm{mmol}^{-1}$ added daily thereafter (M2 additions stopped on Day 19), a steady decline in $\mathrm{PO}_{4}{ }^{3-}$ concentration was observed during the flagellate and diatom bloom. This decline continued during the onset and peak of the bloom of Phaeocystis pouchetii before increasing slightly during the last week of the experiment (Fig. 4a). Concentrations of $\mathrm{H}_{2} \mathrm{SiO}_{3}$ were initially high but decreased rapidly to $<0.5 \mu \mathrm{mol} \mathrm{Si}{ }^{-1}$ by Day 9 in all mesocosms and remained low throughout the rest of the experiment (Fig. 4b).

Generating a mass balance for this experiment was not straightforward. For reasons discussed in the 'Materials and methods', we replaced $10 \%$ of the mesocosm volume with water from the fjord each day. Unfortunately, we do not have ambient concentrations for the fjord water over the entire course of the experiment. However, assuming the ambient concentration of the fjord did not change from the initial concentrations at the beginning of the experiment, and taking into account the $10 \%$ addition of nutrients and fjord water, we were able to calculate mass balances of $\mathrm{N}$ consumption and production. A mass balance was achieved in M1 (control) and M3 over the entire course of the experiment. A mass balance was not achieved in M2; our speculation is that because the bloom in M2 crashed earlier than in M3 there was possibly more export or sedimentation of Phaeocystis pouchetii colonies in M2 that would not be sampled in the water column. This is supported by the fact that we saw more consumption of $\mathrm{N}$ than we measured in production of $\mathrm{N}$. Along similar lines, mass balances were also not achieved for M2 and M3 during the diatom and flagellate bloom period (the increase in biomass and DON did not equal the disappearance of DIN). We believe this is due to a significant amount of export or sedimentation onto the bottom of the mesocosm bags because large diatoms tend to sink out of the system quickly due to their heavy siliceous tests. Unfortunately, we do not have any data on sedimentation rates in the mesocosms. 

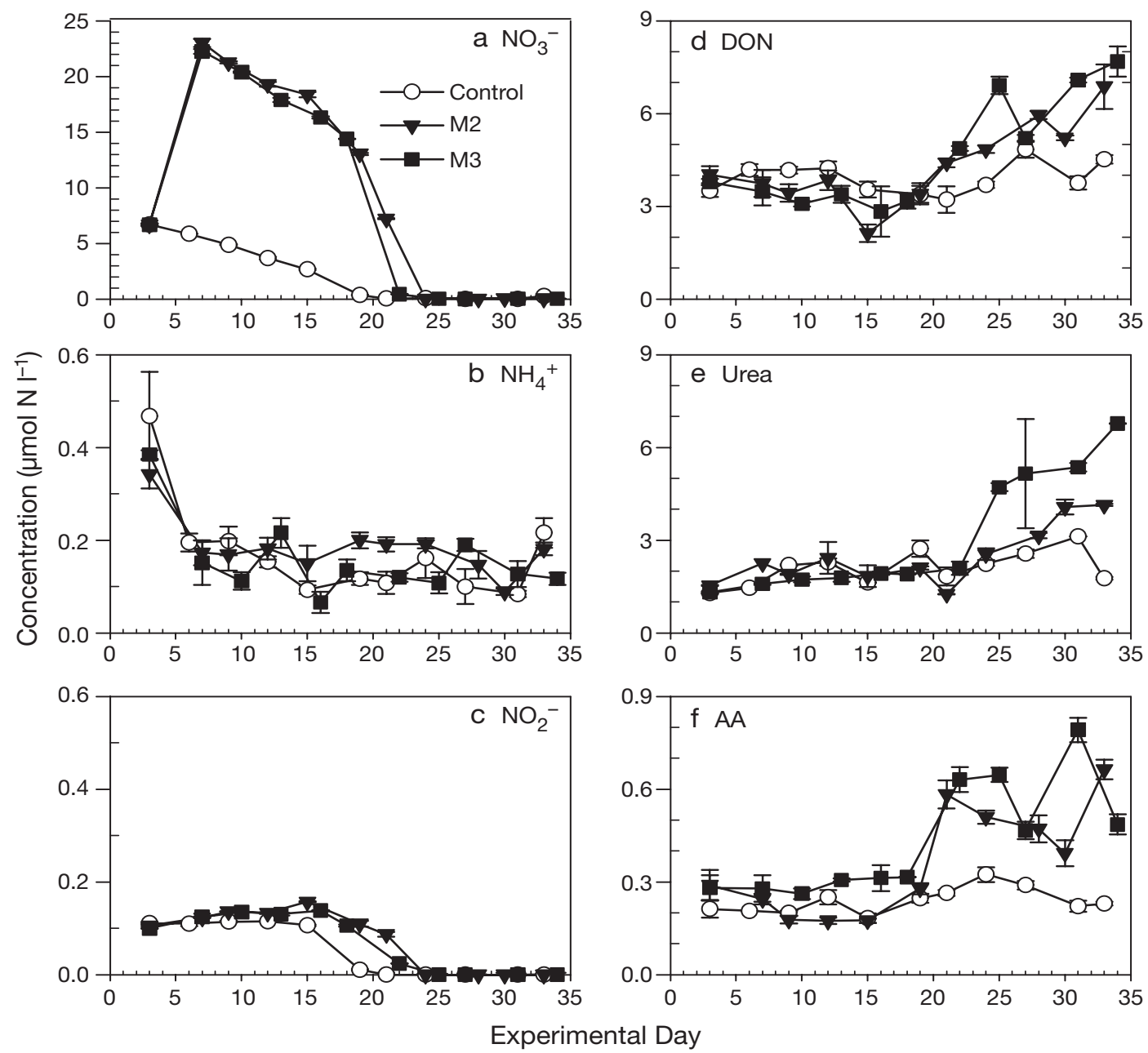

Fig. 3. Concentration of nitrogenous nutrients versus experimental day for inorganic nitrogen forms (a) $\mathrm{NO}_{3}{ }^{-},(\mathrm{b}) \mathrm{NH}_{4}{ }^{+}$and (c) $\mathrm{NO}_{2}{ }^{-}$, and for organic forms (d) dissolved organic nitrogen (DON), (e) urea and (f) amino acids (AA). Error bars represent $\pm \mathrm{SD}_{i}$ when they do not appear they are smaller than the symbols. There are no ambient nitrogen data for Day 4 . Note the differences in scale on the $y$-axes
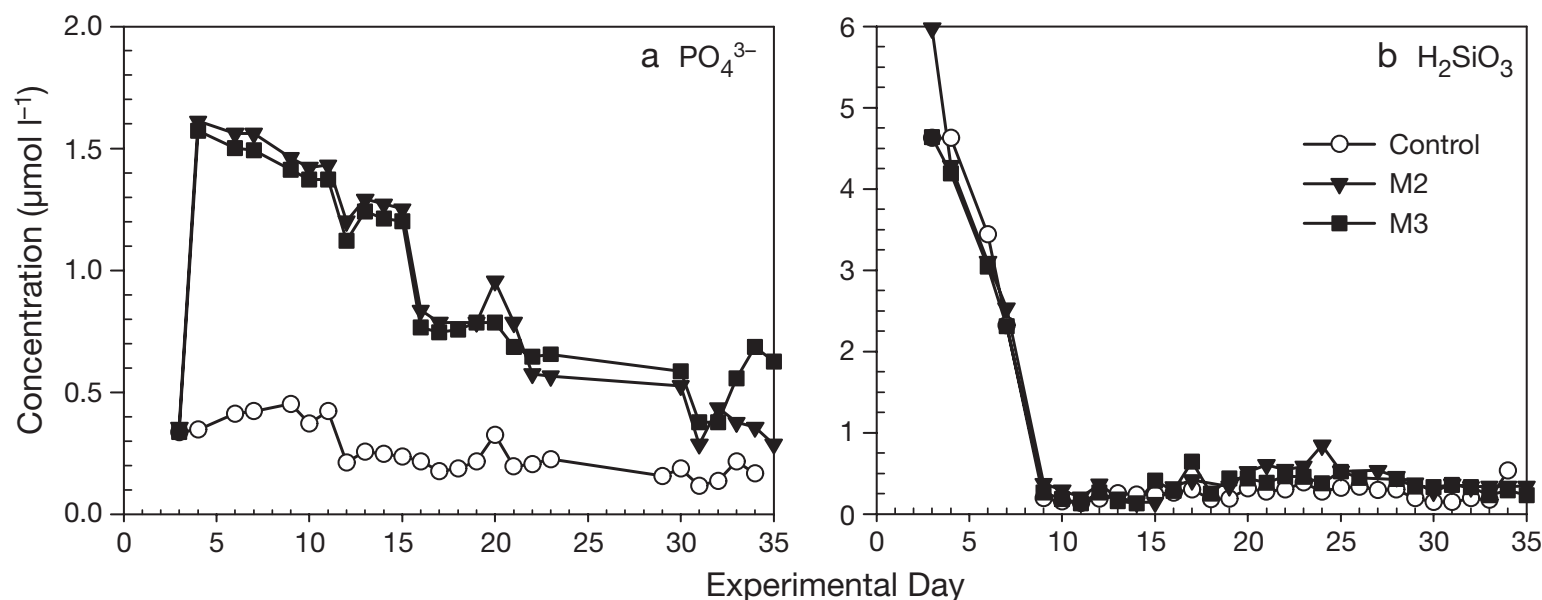

Fig. 4. Concentration of (a) $\mathrm{PO}_{4}{ }^{3-}$ and (b) $\mathrm{H}_{2} \mathrm{SiO}_{3}$ versus experimental day for the control and the 2 nutrient-amended mesocosms, M2 and M3. Note the differences in scale on the $y$-axes 


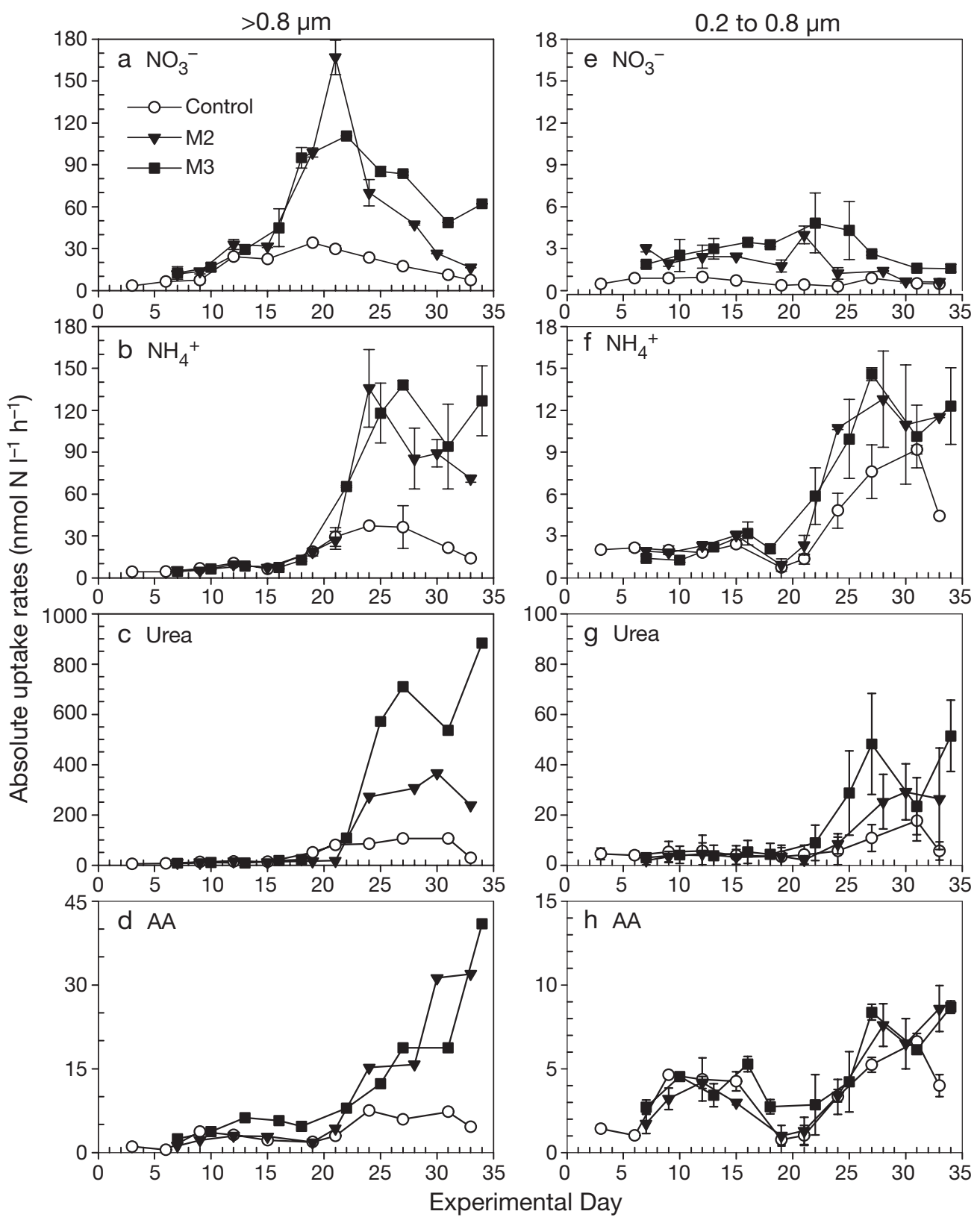

Fig. 5. Absolute uptake rates for $(\mathrm{a}-\mathrm{d})$ the $>0.8 \mu \mathrm{m}$ and $(\mathrm{e}-\mathrm{h})$ the 0.2 to $0.8 \mu \mathrm{m}$ size classes for $(\mathrm{a}, \mathrm{e}) \mathrm{NO}_{3}{ }^{-},(\mathrm{b}, \mathrm{f}) \mathrm{NH}_{4}{ }^{+},(\mathrm{c}, \mathrm{g}) \mathrm{urea}$ and $(\mathrm{d}, \mathrm{h}) \mathrm{AA}$. Error bars represent $\pm \mathrm{SD}$; when they do not appear they are smaller than the symbols (except in panels $\mathrm{c}$ and $\mathrm{d}$ where there are no error bars as noted in 'Materials and methods'). Note the differences in scale on the $y$-axes

\section{Uptake and regeneration rates}

In general, absolute uptake rates of all substrates were similar in all 3 mesocosms over the first $15 \mathrm{~d}$ of the experiment in both the $>0.8 \mu \mathrm{m}$ and 0.2 to $0.8 \mu \mathrm{m}$ size fractions (Fig. 5), with the exception of $\mathrm{NO}_{3}{ }^{-}$ uptake in the bacterial size class (Fig. 5e). In the second half of the present study, uptake rates into the $>0.8 \mu \mathrm{m}$ fraction increased dramatically. Uptake rates of $\mathrm{NO}_{3}{ }^{-}$peaked around Day $23, \mathrm{NH}_{4}{ }^{+}$uptake rates peaked around Day 25, urea uptake rates were maximal at Days 25 to 30, and AA uptake increased near the end of the present study (Fig. 5a-d). Though the control treatment followed a similar pattern, uptake rates were substantially higher in M2 and M3 during the Phaeocystis pouchetii bloom. The highest absolute uptake rates measured were for urea, followed by $\mathrm{NO}_{3}{ }^{-}$and $\mathrm{NH}_{4}{ }^{+}$, and then AA. In the 0.2 to $0.8 \mu \mathrm{m}$ fraction, uptake rates of $\mathrm{NH}_{4}{ }^{+}$, urea and AA increased towards the end of the $P$. pouchetii bloom, while $\mathrm{NO}_{3}{ }^{-}$ 
uptake remained relatively constant or decreased (Fig. 5e-h).

In general, temporal changes in absolute uptake rates (Fig. 5) were closely correlated to changes in specific uptake rates (Fig. 6), suggesting that the cells in all 3 mesocosms were physiologically similar to each other throughout the experiment. As a result, the large differences in absolute uptake rates observed among the control and M2 and M3 mesocosms were due largely to differences in biomass within the mesocosms. Within a given mesocosm, the changes in specific uptake rates over time indicated that the cells were changing physiologically in response to changes in nutrients. The magnitude of specific uptake rates were similar in the $>0.8 \mu \mathrm{m}$ and 0.2 to $0.8 \mu \mathrm{m}$ fractions, in contrast to the large differences observed in the absolute uptake rates between the 2 size fractions. Specific $\mathrm{NO}_{3}{ }^{-}$uptake rates in the $>0.8 \mu \mathrm{m}$ size class increased initially, peaking on Day 12 in the control and on Days 18 and 21 in M2 and M3, respectively (Fig. 6a). In the 0.2 to $0.8 \mu \mathrm{m}$ fraction, specific $\mathrm{NO}_{3}{ }^{-}$ uptake was highest during the flagellate and diatom bloom in all 3 mesocosms (Fig. 6e). In the $>0.8 \mu \mathrm{m}$ and 0.2 to $0.8 \mu \mathrm{m}$ fractions, specific uptake rates of $\mathrm{NH}_{4}{ }^{+}$
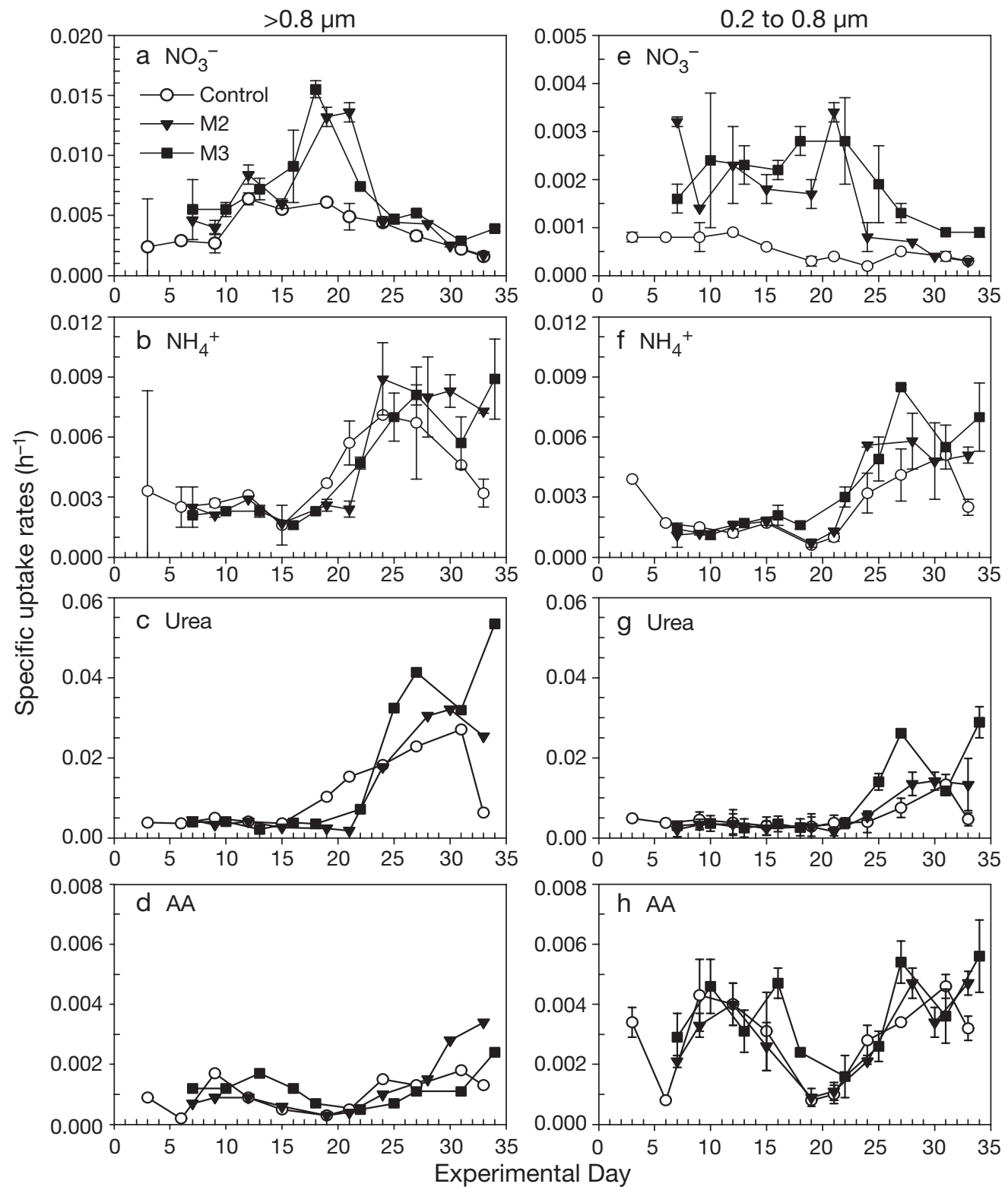

Fig. 6. Specific uptake rates $\left(\mathrm{h}^{-1}\right)$ for $(\mathrm{a}-\mathrm{d})$ the $>0.8 \mu \mathrm{m}$ and $(\mathrm{e}-\mathrm{h})$ the 0.2 to $0.8 \mu \mathrm{m}$ size classes for $(\mathrm{a}, \mathrm{e}) \mathrm{NO}_{3}{ }^{-}($note the difference in scale used for the 2 size classes), $(\mathrm{b}, \mathrm{f}) \mathrm{NH}_{4}{ }^{+},(\mathrm{c}, \mathrm{g})$ urea and $(\mathrm{d}, \mathrm{h}) \mathrm{AA}$. Error bars represent $\pm \mathrm{SD}_{;}$when they do not appear they are smaller than the symbols (except in panels c and d where there are no error bars as noted in 'Materials and methods'). 
were low initially, but increased substantially in all mesocosms (Fig. 6b,f). Regeneration rates of $\mathrm{NH}_{4}^{+}$ were relatively low and of similar magnitude during the first half of the experiment in all 3 mesocosms (Fig. 7). Rates of $\mathrm{NH}_{4}{ }^{+}$regeneration increased during the increase in Phaeocystis pouchetii and were extremely variable during the final third of the experiment. The high variability in regeneration rates is likely due to patchiness in grazers. Though we normally screen out large grazers (i.e. $>100$ to $200 \mu \mathrm{m}$ ) which can have a large effect on a given incubation, we were not able to do so in the present study due to the large size of the $P$. pouchetii colonies.

In the case of specific urea uptake, rates were low during the flagellate and diatom bloom but increased dramatically during the Phaeocystis pouchetii bloom in both size fractions (Fig. 6c,g). Although rates of specific urea uptake were highest in M2 and M3, they also increased in the control before declining in the final days of the experiment. Rates of specific AA uptake in both size fractions peaked during the flagellate and diatom bloom, similar to $\mathrm{NO}_{3}^{-}$uptake, but then increased again during the Phaeocystis bloom (Fig. 6d,h). Specific AA uptake rates were also unique in that rates were higher in the 0.2 to $0.8 \mu \mathrm{m}$ fraction relative to the $>0.8 \mu \mathrm{m}$ fraction.

The $>0.8 \mu \mathrm{m}$ size fraction relied mostly on inorganic $\mathrm{N}$ during the diatom and flagellate bloom in all 3 mesocosms, with $\mathrm{NO}_{3}^{-}$averaging $36 \%$ of uptake in the control and $50 \%$ in M2 and M3 (Fig. 8a-c). During this same time period, the 0.2 to $0.8 \mu \mathrm{m}$ size fraction relied mostly on organic $\mathrm{N}$, with urea averaging $45 \%$ of uptake in the control and 29 and $32 \%$ in M2 and M3, respectively (Fig. 8d-f). AA uptake was also high during the diatom and flagellate bloom in the bacterial

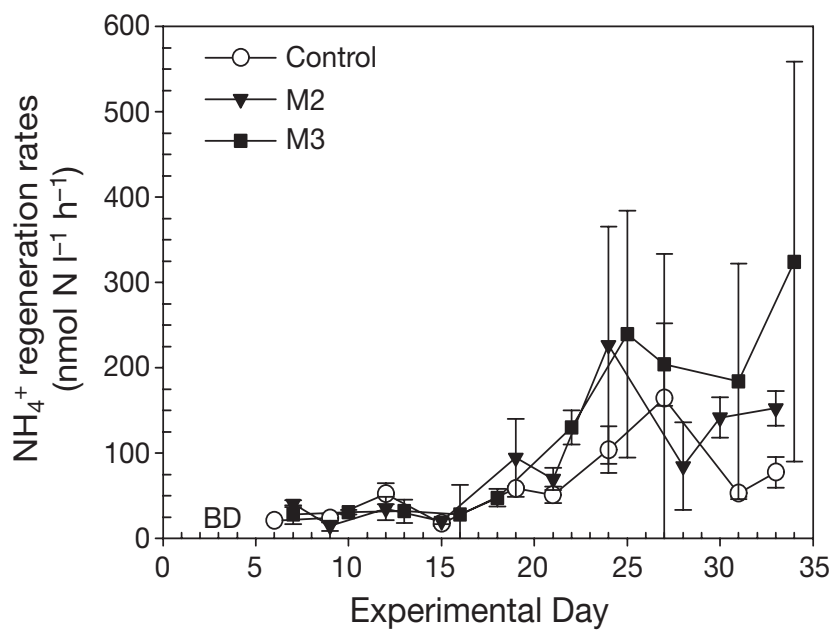

Fig. 7. Ammonium regeneration rates versus experimental day for the control and the 2 nutrient-amended mesocosms, M2 and M3. Error bars represent SD; when they do not appear they are smaller than the symbols size fraction, averaging $27 \%$ of uptake in the control and M2 and $31 \%$ in M3. During the Phaeocystis pouchetii bloom, the $>0.8 \mu \mathrm{m}$ size fraction relied mostly on organic N, particularly urea, which represented an average of 47 to $59 \%$ of uptake in all 3 mesocosms. The bacterial size fraction continued to rely on organic $\mathrm{N}$ during the $P$. pouchetii bloom with urea representing an average of 46 to $54 \%$ of uptake in all 3 mesocosms. Ammonium uptake represented 21 to $26 \%$ of uptake in this size fraction during the $P$. pouchetii bloom, which was slightly more than AA uptake (14 to $20 \%$ ).

\section{DISCUSSION}

As observed in similar mesocosm experiments, the addition of $\mathrm{NO}_{3}{ }^{-}$and $\mathrm{PO}_{4}{ }^{3-}$ ultimately resulted in a large phytoplankton bloom dominated by the prymnesiophyte, Phaeocystis sp. (e.g. Fernández et al. 1992, Egge \& Heimdal 1994). In the present mesocosm study, a small bloom of flagellates and diatoms developed during the first $15 \mathrm{~d}$ before Phaeocystis pouchetii colonies started to accumulate and any major differences between amended mesocosms and the control were apparent. Our results are similar to naturally occurring P. pouchetii blooms, where spring blooms of colonial $P$. pouchetii form yearly in many northern latitudes (Barrents Sea, fjords of Norway, North Sea; Heimdal 1974, Erga \& Heimdal 1984, Wassmann et al. 2005). Typically, P. pouchetii blooms follow a diatom bloom that forms in nutrient-rich waters. It is hypothesized that the input of nutrients via winter mixing or river runoff (or the addition of $\mathrm{NO}_{3}{ }^{-}$and $\mathrm{PO}_{4}{ }^{3-}$ in a mesocosm study) fuels a bloom of diatoms, which are known to rapidly take advantage of new inputs of nutrients (especially $\mathrm{NO}_{3}{ }^{-}$) in the presence of $\mathrm{H}_{2} \mathrm{SiO}_{3}$. As the $\mathrm{H}_{2} \mathrm{SiO}_{3}$ is depleted and $\mathrm{PO}_{4}{ }^{3-}$ is drawn down, $P$. pouchetii are poised to start blooming. Blooms of phytoplankton supported by inorganic nutrients followed by blooms of an HAB species that is poorly grazed and supported by regenerated organic nutrients are seen in many HAB studies (e.g. Laroche et al. 1997, Sunda et al. 2006 and references therein). Since $P$. pouchetii are also considered detrimental to ecosystems (Schoemann et al. 2005, Verity et al. 2007a) they can be considered HABs or ecosystem disruptive algal blooms (EDABs, Sunda et al. 2006). Many HAB species occur in nutrient-enriched areas after a previous bloom of a non-HAB species has utilized inorganic nutrients and started to decline. The prebloom provides recycled nutrients that are often in forms not immediately available to HAB species and therefore cause a lag between the introduction of nutrients and an HAB event; this was seen in the present mesocosm study, 

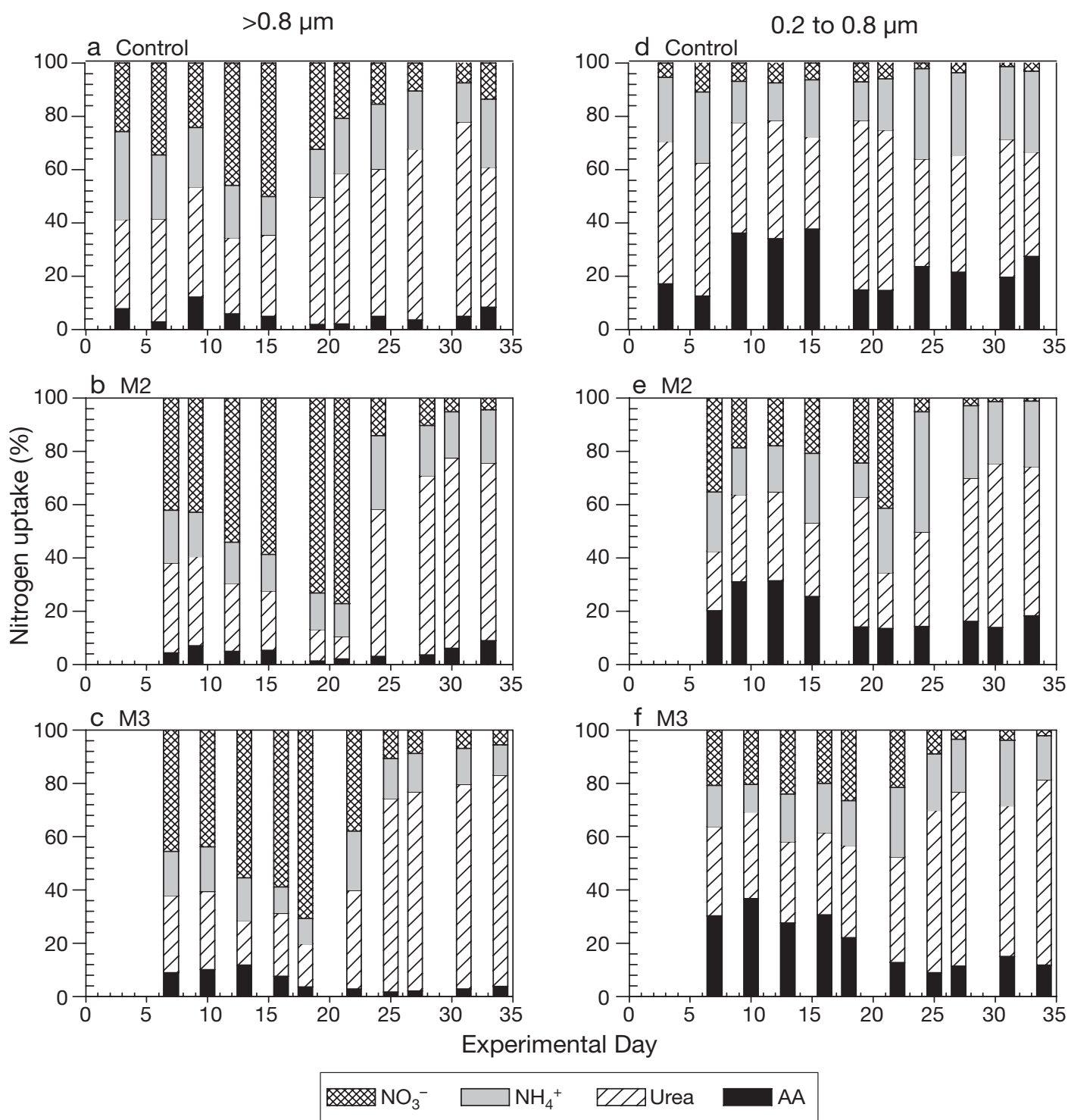

Fig. 8. Percent of nitrogen uptake for $(\mathrm{a}-\mathrm{C})$ the $>0.8 \mu \mathrm{m}$ and $(\mathrm{d}-\mathrm{f})$ the 0.2 to $0.8 \mu \mathrm{m}$ size fractions due to $\mathrm{NO}_{3}{ }^{-}, \mathrm{NH}_{4}{ }^{+}$, urea and AA over the course of the experiment for $(\mathrm{a}, \mathrm{d})$ control, $(\mathrm{b}, \mathrm{e}) \mathrm{M} 2$ and $(\mathrm{c}, \mathrm{f}) \mathrm{M} 3$ mesocosms

with a few days lag time before the $P$. pouchetii bloom, as well as in studies of Aureococcus blooms (Laroche et al. 1997).

Studies of $\mathrm{N}$ uptake dynamics during the onset of a Phaeocystis pouchetii bloom are sparse, especially those that include both inorganic and organic $\mathrm{N}$ forms $\left(\mathrm{NO}_{3}{ }^{-}\right.$and $\mathrm{NH}_{4}{ }^{+}$, Muggli \& Smith $1993 ; \mathrm{NO}_{3}{ }^{-}, \mathrm{NH}_{4}{ }^{+}$and urea, Tungaraza et al. 2003) and those that include competition between phytoplankton and bacteria for these nutrients (Lancelot \& Billen 1984, Lancelot \& Mathot 1987). Below we highlight the development and decline of the flagellate and diatom and Phaeocystis pouchetii blooms with respect to critical nutrient pools and competition between phytoplankton and bacteria.

\section{Flagellate and diatom bloom}

During the first few days of the experiment all 3 enclosures behaved similarly. Particulate $\mathrm{N}$ and chl a concentrations increased at similar rates, due primarily to an increase in diatoms and small phototrophic algae other than Phaeocystis pouchetii. During the flagellate and diatom bloom, $P$. pouchetii was present only as solitary cells; the number of colonial forms began to increase around Day 12 in M2 and M3, but always remained low in the control (Nejstgaard et al. 2006). At first, the PN pool included some detrital N, as ratios of PN:chl a were initially high; however, as the blooms progressed the PN pool was increasingly dominated by 
healthy growing phytoplankton populations, demonstrated by the PN:chl a ratio approaching 1:1 (McCarthy et al. 1977).

Levels of $\mathrm{NO}_{3}{ }^{-}$and $\mathrm{PO}_{4}{ }^{3-}$ were initially high enough for Phaeocystis pouchetii blooms to occur in the present study; however, they were likely out-competed by small phototrophic algae and by diatoms during the first $15 \mathrm{~d}$. Small phototrophic flagellates started to increase in numbers first, but as diatoms started to bloom, the flagellate bloom decreased (Fig. 2). Diatoms, however, were only able to out-compete $P$. pouchetii when there was sufficient $\mathrm{H}_{2} \mathrm{SiO}_{3}$ present to support their growth (Fig. 4). Egge \& Aksnes (1992) observed diatom blooms in mesocosm studies when $\mathrm{H}_{2} \mathrm{SiO}_{3}$ concentrations were $>2 \mu \mathrm{mol} \mathrm{Si}{ }^{-1}$, suggesting that a minimum concentration of $2 \mu \mathrm{mol} \mathrm{Si} \mathrm{l^{-1 }}$ is required before $\mathrm{H}_{2} \mathrm{SiO}_{3}$ is utilized. Paasche (1973) found that $\mathrm{H}_{2} \mathrm{SiO}_{3}$ uptake does not necessarily follow typical Michaelis-Menten kinetics and argued that a threshold concentration of 0.3 to $1.3 \mu \mathrm{mol} \mathrm{Si} \mathrm{l}^{-1}$ is required for $\mathrm{H}_{2} \mathrm{SiO}_{3}$ uptake. In the present study $\mathrm{H}_{2} \mathrm{SiO}_{3}$ concentrations started out above this threshold, but were drawn down to below $1.2 \mu \mathrm{mol} \mathrm{Si} \mathrm{l}^{-1}$ between Days 7 and 9, and the concentration was well below $0.5 \mu \mathrm{mol} \mathrm{Si} \mathrm{l}^{-1}$ after Day 9. This utilization of $\mathrm{H}_{2} \mathrm{SiO}_{3}$ corresponded with an increase in the number of diatoms in each mesocosm; as the $\mathrm{H}_{2} \mathrm{SiO}_{3}$ was depleted, the small bloom of diatoms dissipated.

As the flagellate and diatom bloom developed, the concentration of TDN decreased to ca. $5 \mu \mathrm{mol} \mathrm{N}{ }^{-1}$, due to the near depletion of $\mathrm{NO}_{3}{ }^{-}$and $\mathrm{NO}_{2}{ }^{-}$, as well as the drawn-down $\mathrm{NH}_{4}{ }^{+}$. Concentrations of DON were very low at the start of the experiment and comparable to levels found in the open ocean. There was little change in the organic $\mathrm{N}$ forms during the formation of the flagellate and diatom bloom, suggesting that regeneration processes were adequate to balance the measured uptake of urea and AA (Fig. 5). Data suggest that the rise of the diatom bloom in all 3 mesocosms was most likely due to diatoms out-competing the small phototrophic algae for available inorganic $\mathrm{N}$ sources and that the decline was due to the depletion of $\mathrm{H}_{2} \mathrm{SiO}_{3}$. An alternative hypothesis is that a rapid response in grazing pressure from zooplankton contributed to the decline of the flagellate and diatom bloom. However, the biomass of both micrograzers (Fig. 2) and copepods was very low compared to the total phytoplankton during the flagellate and diatom bloom in all mesocosms, as well as during the Phaeocystis pouchetii bloom in M2 and M3 (Nejstgaard et al. 2006). Thus, it is unlikely that grazers could significantly affect the development of the major phytoplankton groups. At this stage the mesocosms appeared to be mimicking an area dominated by new production that was uncoupled with respect to phytoplankton and their grazers.
To directly study the affect of grazing during our $34 \mathrm{~d}$ experiment, mesozooplankton and microzooplankton experiments were conducted (J. C. Nejstgaard et al. unpubl.) with water from M2 during 3 periods of $24 \mathrm{~h}$ (March 12-13, 15-16 and 24-25) using a standard bottle incubation dilution technique as described in Nejstgaard et al. (2001b). The dilution studies clearly show that the microzooplankton community did not have any statistically significant grazing impact on the smaller-sized phytoplankton (caught on 0.45 to $8 \mu \mathrm{m}$ filters) during any of the $24 \mathrm{~h}$ periods. For the $>8 \mu \mathrm{m}$ phytoplankton community, grazing was also negligible during the first 2 periods (grazing removed only 11 to $18 \%$ of the phytoplankton standing stock per day). In contrast, during the third period (March 24-25) the microzooplankton community removed ca. $63 \%$ of the standing stock per day and thus may have contributed to the decline of the larger phytoplankton bloom only at that stage. In general, however, as expected from the low microzooplankton abundances, the grazing impact by the microzooplankton on the phytoplankton appeared to be minor (J. C. Nejstgaard et al. 2006). Further, preliminary experimental data (Nejstgaard et al. unpubl.) also suggest that direct grazing by the mesozooplankton had only a minor effect on the phytoplankton directly. The mesozooplankton, however, may have kept the microzooplankton at a relatively low abundance, as seen in previous mesocosm experiments at this site (e.g. Nejstgaard et al. 2001a) and so affected the phytoplankton community indirectly.

We observed no major difference between the control and the nutrient-amended mesocosms in either absolute or specific uptake rates for $\mathrm{NH}_{4}{ }^{+}$, urea and $\mathrm{AA}$ in either size class during the flagellate and diatom bloom. During the flagellate and diatom bloom, the largest differences between mesocosms were observed for $\mathrm{NO}_{3}{ }^{-}$uptake (both absolute and specific) in the 0.2 to $0.8 \mu \mathrm{m}$ size classes, where the $\mathrm{NO}_{3}{ }^{-}$and $\mathrm{PO}_{4}{ }^{3-}$-amended mesocosms had rates 2 to 3 times higher than in the control. Several investigators have reported high $\mathrm{NO}_{3}{ }^{-}$utilization rates by bacteria (Horrigan et al. 1988, in cultures; Kirchman et al. 1991, in the North Atlantic). Recent work in the Barents Sea also demonstrated high rates of $\mathrm{NO}_{3}{ }^{-}$utilization by the bacterial size class (Allen et al. 2002). Allen et al. (2002) suggest that the high rates observed are a function of high ambient $\mathrm{NO}_{3}{ }^{-}$concentrations, as in the case of our nutrient-amended mesocosms. Although bacterial abundance and production increased during the flagellate and diatom bloom period, the increase was observed in all 3 mesocosms. This suggests that the higher rates of $\mathrm{NO}_{3}{ }^{-}$uptake observed in the 2 nutrient-amended mesocosms for the bacterial fraction were not due 
solely to the elevated $\mathrm{NO}_{3}{ }^{-}$concentrations (M. E. Frischer et al. unpubl. data). Although outside the scope of the present study, the composition of bacteria communities in each mesocosm was investigated by DGGE analysis of amplified 16S rDNA genes to assess whether nutrient additions resulted in the development of distinct bacterial communities. The results of these investigations suggest that bacterial communities were similar in the fertilized and unfertilized mesocosms, and so it seems unlikely that differences in bacterial community composition would explain higher $\mathrm{NO}_{3}^{-}$uptake rates in the fertilized treatments (M. E. Frischer et al. unpubl.).

During the flagellate and diatom bloom, the $>0.8 \mu \mathrm{m}$ size fraction in the control mesocosm utilized both new $\left(\mathrm{NO}_{3}{ }^{-}\right)$and regenerated $\left(\mathrm{NH}_{4}{ }^{+}\right.$and urea) forms of $\mathrm{N}$ (Fig. 8a). The 0.2 to $0.8 \mu \mathrm{m}$ size class in the control treatment, however, relied primarily on regenerated forms of $\mathrm{N}$, with urea uptake rates being the highest (Figs. 5 \& 8d). The nutrient-amended mesocosms (M2 and M3) were characteristic of an area dominated by new production, relying primarily on $\mathrm{NO}_{3}{ }^{-}$in the $>0.8 \mu \mathrm{m}$ fraction (Fig. 8b,c).

Bacterial $\mathrm{N}$ demand (BND, \%) was estimated based on bacterial productivity using a stoichiometric conversion factor of $5.2(\mathrm{C}: \mathrm{N})$ determined for exponentially growing bacterioplankton in Raunefjord (Vrede et al. 2002). Bacterial production in terms of $\mathrm{N}$ was then compared to absolute uptake rates of the 0.2 to $0.8 \mu \mathrm{m}$ fraction to determine BND. We found that $\mathrm{NH}_{4}{ }^{+}, \mathrm{NO}_{3}{ }^{-}$, urea and AA could account for 33 to $96 \%$ of BND during the flagellate and diatom bloom (Fig. 9). The organic forms accounted for the majority of the BND (urea 10 to $44 \%$, AA 9 to $29 \%$ ), as was also demonstrated by $\mathrm{N}$ uptake in the 0.2 to $0.8 \mu \mathrm{m}$ size class. Some studies of BND have shown that AA and $\mathrm{NH}_{4}{ }^{+}$ are the major sources of bacterial N (Fuhrman 1990, Keil \& Kirchman 1991); however, several more recent studies have demonstrated that urea can be a major source of $\mathrm{N}$ to bacteria (Middelboe et al. 1998, Jørgensen et al. 1999, Jørgensen 2006), as we have observed in the present study. These data further suggest that additional $\mathrm{N}\left(\mathrm{NO}_{2}{ }^{-}\right.$and/or other organics) were likely used by the bacterial fraction during the experiment.

\section{Phaeocystis pouchetii bloom}

The flagellate and diatom bloom was followed by a large increase in the abundance of Phaeocystis pouchetii colonies present in the mesocosms. It has been hypothesized that the transition from solitary to colonial forms may provide a refuge for $P$. pouchetii from predation (Fernández et al. 1992) and/or from
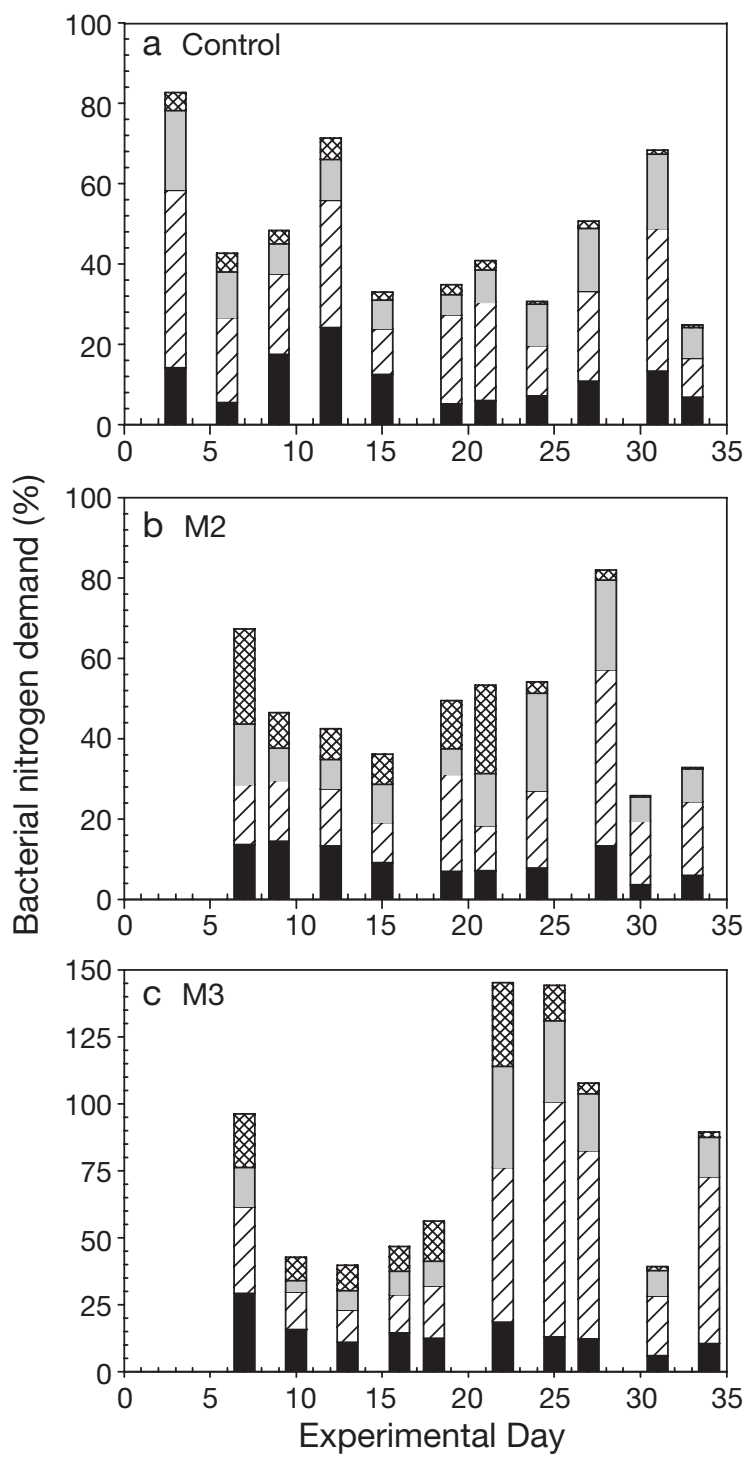

$\mathrm{NO}_{3}{ }^{-} \square \mathrm{NH}_{4}{ }^{+} \mathrm{ZCZ}$ Urea

Fig. 9. Percent of bacterial nitrogen demand (0.2 to $0.8 \mu \mathrm{m}$ size fraction) due to $\mathrm{NO}_{3}{ }^{-}, \mathrm{NH}_{4}{ }^{+}$, urea and $\mathrm{AA}$ over the course of the experiment for (a) control, (b) M2 and (c) M3 mesocosms

viral infection, as solitary forms are susceptible to viral attack while colonial forms are not (e.g. Bratbak et al. 1998, Jacobsen et al. 2007). It is also hypothesized that colony formation may assist in buoyancy control, keeping cells in the upper layers of the euphotic zone (Skreslet 1988). During the colonial period of the bloom, large differences between the control and nutrient-amended mesocosms became apparent. The bloom of $P$. pouchetii was only observed in the 2 mesocosms amended with $\mathrm{NO}_{3}{ }^{-}$and $\mathrm{PO}_{4}{ }^{3-}$. Concentrations of $\mathrm{chl}$ a reached a maximum on 
Day 25 and declined more rapidly in M2 than in M3, most likely because nutrient amendment of M2 was stopped on Day 19. Concentrations of PN reached a maximum at the same time as chl a concentrations peaked. The concentration of $\mathrm{PN}$ is a measurement of all PN including decaying phytoplankton and detritus. As a result, PN remained elevated throughout the decline of the $P$. pouchetii bloom, while PN:chl a, which had been close to 1:1 during the peak of the $P$. pouchetii bloom, increased as detrital $\mathrm{N}$ accumulated in the PN pool.

During the Phaeocystis pouchetii bloom (Days 18 to $34)$, concentrations of DON increased, likely due to the decline of the flagellate and diatom bloom. The decline of phytoplankton blooms is often a time of enhanced organic matter release due to processes such as physiological stress or high grazing pressure (e.g. Carlson 2002). Increases in organic carbon release have been observed with blooms of $P$. pouchetii (e.g. Lancelot 1983); therefore, increases in DON may also be associated with these blooms. Heterotrophic flagellates and ciliates also increased in all 3 mesocosms during the $P$. pouchetii bloom. Their increase, as well as a lack of inorganic nutrients, appears to have been sufficient to keep any large phytoplankton blooms from forming in the control mesocosm and suggests a tightly coupled system between phytoplankton and grazers. In the nutrient-amended mesocosms, however, the rapid growth of $P$. pouchetii (especially colonies, Nejstgaard et al. 2006, Fig. 6) and the slower growth of grazers allowed the system to become uncoupled. A number of factors likely contributed to the initiation of the $P$. pouchetii bloom including $\mathrm{H}_{2} \mathrm{SiO}_{3}$ depletion, high $\mathrm{NO}_{3}{ }^{-}$concentrations and reduced $\mathrm{PO}_{4}{ }^{3-}$ availability. $\mathrm{H}_{2} \mathrm{SiO}_{3}$ was depleted by Day 9, at which time diatom numbers declined, reducing competition with $P$. pouchetii. The decline in $\mathrm{H}_{2} \mathrm{SiO}_{3}$ and resulting decrease in diatom numbers is unlikely to have triggered the $P$. pouchetii bloom, however, because $P$. pouchetii did not begin to increase in numbers until Day 16. Nitrogen availability is also unlikely as the key to initiation because $\mathrm{NO}_{3}{ }^{-}$was present at high concentrations $\left(>15 \mathrm{umol} \mathrm{l}^{-1}\right)$ during the time prior to the increase in $P$. pouchetii. Early in the experiment, $\mathrm{PO}_{4}{ }^{3-}$ concentrations were also high. Veldhuis \& Admiraal (1987) found that P. pouchetii colonies bloom in culture only when $\mathrm{PO}_{4}{ }^{3-}$ concentrations are below $1 \mu \mathrm{mol} \mathrm{l}^{-1}$. This is consistent with our observations: phosphorus fell to below $1 \mu \mathrm{mol} \mathrm{l}^{-1}$ on Day 16, the day on which $P$. pouchetii colonies first appeared, and thereafter $P$. pouchetii numbers increased dramatically.

Initial concentrations of urea during the present study were somewhat high $\left(1.2 \mu \mathrm{mol} \mathrm{N}{ }^{-1}\right)$ for coastal areas; however, Tungaraza et al. (2003) have reported even higher urea concentrations of up to $6 \mu \mathrm{mol} \mathrm{N}{ }^{-1}$ in a coastal area of the North Sea, although their site is subject to anthropogenic discharges. Large increases in urea concentration during the present study were observed in the nutrient-amended mesocosms where Phaeocystis pouchetii bloomed and not in the control mesocosm, suggesting that urea was coming from regeneration processes and not anthropogenic sources when water was added to the mesocosms. Similarly, regeneration rates of $\mathrm{NH}_{4}{ }^{+}$were roughly 2 times higher in the nutrient-amended mesocosms than in the control. This observation, along with uptake rate data, suggests that the nutrient-amended mesocosms were relying on regenerated forms of $\mathrm{N}$ during the $P$. pouchetii bloom (Fig. 8b,c,e,f). A reliance on organics was also seen in the 0.2 to $0.8 \mu \mathrm{m}$ size class, for which BND was met mostly by urea (11 to $44 \%$ in M2, 22 to $88 \%$ in M3), followed by $\mathrm{NH}_{4}{ }^{+}$and $\mathrm{AA}$, with $\mathrm{NO}_{3}{ }^{-}$contributing the least. These $4 \mathrm{~N}$ substrates could account for 26 to $145 \%$ of the total BND during the P. pouchetii bloom. Jørgensen (2006) reported similar observations associated with a spring bloom in Roskilde Fjord (Denmark) and in bacterial culture studies of isolates from Knebel Vig and Limfjorden (Denmark), where urea accounted for $>30 \%$ of the BND, which exceeded the BND met by AA. In the present study, urea met the majority of the BND during both the flagellate and diatom and Phaeocystis blooms in all mesocosms, once again suggesting that urea, when available, can be a major source of $\mathrm{N}$ to the bacterial community.

During the Phaeocystis pouchetii bloom, the DON pool comprised largely labile urea and AA (>93\%), and organic forms of $\mathrm{N}$ were highly utilized. The crash of the $P$. pouchetii blooms was likely due to $\mathrm{PO}_{4}{ }^{3-}$ depletion and perhaps a moderate increase in grazing pressure from the microzooplankton. Supporting the idea of P limitation, Riegman et al. (1992) found that Phaeocystis spp. are poor competitors under low P conditions. Viral abundance in the present study increased in all 3 mesocosms, with slightly higher numbers in the 2 nutrient-amended mesocosms, suggesting that viral infection is another factor that may have contributed to the decline of the $P$. pouchetii bloom (Ruardij et al. 2005, Jacobsen et al. 2007).

\section{CONCLUSIONS}

In summary, addition of $\mathrm{NO}_{3}{ }^{-}$and $\mathrm{PO}_{4}{ }^{3-}$ to our mesocosms eventually resulted in a large bloom of Phaeocystis pouchetii. Urea was a highly utilized form of $\mathrm{N}$ in both the phytoplankton and bacterial size classes. Overall, in the bacterial size class, organic N (urea and AA) accounted for the largest percentages of total uptake in all 3 mesocosms. In contrast to urea, AA did not appear to be a major source of $\mathrm{N}$ for the $>0.8 \mu \mathrm{m}$ 
size class. In the bacterial size class, however, specific uptake rates of AA were often equal to or greater than those measured for $\mathrm{NH}_{4}^{+}$, suggesting that organic $\mathrm{N}$, especially urea, may be playing a more important role in the nitrogenous nutrition of both phytoplankton and bacteria in these high-latitude waters than previously thought. As hypothesized, inorganic $\mathrm{N}$ was relatively more important early in the experiment when the mesocosms were representative of an area dominated by new production. Also as hypothesized, we observed an increase in bacterial utilization of $N$, especially organic $\mathrm{N}$, towards the end of the experiment. The succession we observed was from a system dominated by the classic food web, with high amounts of new production, to a system dominated by the microbial loop, with high amounts of regenerated production.

Acknowledgements. We thank the staff at the University of Bergen's Marine Biological Station in Espegrend, Norway, for their assistance, especially A. Aadnesen, H. Gjertsen and T. Sørlie. We are also grateful for help from the participants involved in the mesocosm experiment, including $\mathrm{A}$. Alderkamp, J. Anderson, S. Borrett, J. Brofft, G. Smalley, B. Patten, M. van Rijssel, T. Walters, S. Whipple and M. Zirbel. We thank K. Filippino, E. Skjoldal and S. Torkildsen for assistance with nutrient analysis. Funding for this project was provided by DOE grant DE-FG0298ER62531 to D.A.B., DOE grant FG02-98EF 62531 to M.E.F., Norwegian Research Council grant 152714/120 to J.C.N. and NSF grant OPP-0083381 to P.G.V. This paper is contribution \#2931 of the Virginia Institute of Marine Science, The College of William and Mary.

\section{LITERATURE CITED}

Allen AE, Howard-Jones MH, Booth MG, Frischer ME, Verity PG, Bronk DA, Sanderson MP (2002) Importance of heterotrophic bacterial assimilation of ammonium and nitrate in the Barents Sea during summer. J Mar Syst 38:93-108

Berman T, Bronk DA (2003) Dissolved organic nitrogen: a dynamic participant in aquatic ecosystems. Aquat Microb Ecol 31:279-305

Bratbak G, Jacobsen A, Heldal M (1998) Viral lysis of Phaeocystis pouchetii and bacterial secondary production. Aquat Microb Ecol 16:11-16

Bronk DA, Glibert PM, Ward BB (1994) Nitrogen uptake, dissolved organic nitrogen release, and new production. Science 265:1843-1846

Bronk DA, Glibert PM, Malone TC, Banahan S, Sahlsten E (1998) Inorganic and organic nitrogen cycling in Chesapeake Bay: autotrophic versus heterotrophic processes and relationships to carbon flux. Aquat Microb Ecol 15: 177-189

Bronk DA, Lomas MW, Glibert PM, Schukert KJ, Sanderson MP (2000) Total dissolved nitrogen analysis: comparisons between the persulfate, UV and high temperature oxidation methods. Mar Chem 69:163-178

Carlson CA (2002) Production and removal processes. In: Hansell DA, Carlson CA (eds) Biogeochemistry of marine dissolved organic matter. Academic Press, Amsterdam, p 91-151
Charlson RJ, Lovelock JE, Andreae MO, Warren SG (1987) Oceanic phytoplankton, atmospheric sulphur, cloud albedo and climate. Nature 326:655-661

> Dudek N, Brzezinski MA, Wheeler PA (1986) Recovery of ammonium nitrogen by solvent extraction for the determination of relative ${ }^{15} \mathrm{~N}$ abundance in regeneration experiments. Mar Chem 18:59-69

Dugdale RC, Goering JJ (1967) Uptake of new and regenerated forms of nitrogen in primary productivity. Limnol Oceanogr 12:196-206

> Egge JK, Aksnes DL (1992) Silicate as regulating nutrient in phytoplankton competition. Mar Ecol Prog Ser 83:281-289

Egge JK, Heimdal BR (1994) Blooms of phytoplankton including Emiliania huxleyi (Haptophyta). Effects on nutrient supply in different N:P ratios. Sarsia 79:333-348

Egge JK, Jacobsen A (1997) Influence of silicate on particulate carbon production in phytoplankton. Mar Ecol Prog Ser 147:219-230

Eilertsen HC, Raa J (1995) Toxins in seawater produced by a common phytoplankter: Phaeocystis pouchetii. J Mar Biotechnol 3:115-119

Erga SR, Heimdal BR (1984) Ecological studies on the phytoplankton of Korsfjorden, western Norway. The dynamics of a spring bloom seen in relation to hydrographical conditions and light regime. J Plankton Res 6:67-90

Fernández E, Serret P, de Madariaga I, Harbour DS, Davies AG (1992) Photosynthetic carbon metabolism and biochemical composition of spring phytoplankton assemblages enclosed in microcosms: the diatom - Phaeocystis sp. succession. Mar Ecol Prog Ser 90:89-102

> Fuhrman J (1990) Dissolved free amino acid cycling in an estuarine overflow plume. Mar Ecol Prog Ser 66:197-203

Glibert PM, Lipschultz F, McCarthy JJ, Altabet MA (1982) Isotope dilution models of uptake and remineralization of ammonium by marine plankton. Limnol Oceanogr 27: $639-650$

Heimdal BR (1974) Composition and abundance of phytoplankton in the Ullsfjord area, North Norway. Astarte: J Arctic Biol 7:17-42

Horrigan SG, Hagström ^, Koike I, Azam F (1988) Inorganic nitrogen utilization by assemblages of marine bacteria in seawater culture. Mar Ecol Prog Ser 50:147-150

Jacobsen A, Larsen A, Martinez-Martinez J, Verity PG, Frischer ME (2007) Susceptibility of colonies and colonial cells of Phaeocystis pouchetii (Haptophyta) to viral infection. Aquat Microb Ecol 48:105-112

> Jørgensen NOG (2006) Uptake of urea by estuarine bacteria. Aquat Microb Ecol 42:227-242

Jørgensen NOG, Tranvik LJ, Berg GM (1999) Occurrence and bacterial cycling of dissolved nitrogen in the Gulf of Riga, the Baltic Sea. Mar Ecol Prog Ser 191:1-18

Keil RG, Kirchman DL (1991) Contributions of dissolved free amino acids and ammonium to the nitrogen requirements of heterotrophic bacterioplankton. Mar Ecol Prog Ser 73: $1-10$

Kirchman DL, Ducklow HW (1993) Estimating conversion factors for the thymidine and leucine methods for measuring bacterial production. In: Kemp PF, Sherr BF, Sherr EB, Cole JJ (eds) Handbook of methods in aquatic microbial ecology. Lewis Publishers, Boca Raton, FL, p 513-517

> Kirchman DL, Keil RG, Wheeler PA (1989) The effect of amino acids on ammonium utilization and regeneration by heterotrophic bacteria in the subarctic Pacific. Deep-Sea Res 36:1763-1776

Kirchman DL, Suzuki Y, Garside C, Ducklow HW (1991) High turnover rates of dissolved organic carbon during a spring phytoplankton bloom. Nature 352:612-614 
Koroleff F (1983) Determination of ammonium. In: Grasshoff K, Ehrhardt M, Kremling F (eds) Methods of seawater analysis, 2nd edn. Verlag Chemie, Weinheim, p 150-157

Lancelot C (1983) Factors affecting phytoplankton extracellular release in the Southern Bight of the North Sea. Mar Ecol Prog Ser 12:115-121

$>$ Lancelot C, Mathot S (1987) Dynamics of a Phaeocystis-dominated spring bloom in Belgian coastal waters. I. Phytoplankton activities and related parameters. Mar Ecol Prog Ser 37:239-248

Lancelot C, Billen G (1984) Activity of heterotrophic bacteria and its coupling to primary production during the spring phytoplankton bloom in the southern bight of the North Sea. Limnol Oceanogr 29:721-730

Laroche J, Nuzzi R, Waters R, Wyman K, Falkowski PG, Wallace DWR (1997) Brown tide blooms in Long Island's coastal waters linked to interannual variability in groundwater flow. Glob Change Biol 3:397-410

Larsen A, Fonnes Flaten GA, Sandaa RA, Castberg T and others (2004) Spring phytoplankton bloom dynamics in Norwegian coastal waters: microbial community succession and diversity. Limnol Oceanogr 49:180-190

Liebig J (1840) Organic chemistry in its application to agriculture and physiology, 1st edn. Taylor \& Walton, London

Lomas MW, Lipschultz F (2006) Forming the primary nitrite maximum: nitrifiers or phytoplankton? Limnol Oceanogr 51:2453-2467

Lomas MW, Trice TM, Glibert PM, Bronk DA, McCarthy JJ (2002) Temporal and spatial dynamics of urea concentrations in Chesapeake Bay: biological versus physical forcing. Estuaries 25:469-482

McCarthy JJ, Taylor WR, Taft JL (1977) Nitrogenous nutrition of the plankton in the Chesapeake Bay. I. Nutrient availability and phytoplankton preferences. Limnol Oceanogr 22:996-1011

Middelboe M, Kroer N, Jørgensen NOG, Pakulski D (1998) Influence of sediment on pelagic carbon and nitrogen turnover in a shallow Danish estuary. Aquat Microb Ecol 14:81-90

Muggli DL, Smith WO (1993) Regulation of nitrate and ammonium uptake in the Greenland Sea. Mar Biol 115:199-208

Nejstgaard JC, Hygum BH, Naustvoll LJ, Båmstedt U (2001a) Zooplankton growth, diet and reproductive success compared in simultaneous diatom- and flagellate-microzooplankton-dominated plankton blooms. Mar Ecol Prog Ser 221:77-91

> Nejstgaard JC, Naustvoll LJ, Sazhin A (2001b) Correcting for underestimation of microzooplankton grazing in bottle incubation experiments with mesozooplankton. Mar Ecol Prog Ser 221:59-75

Nejstgaard JC, Frischer ME, Verity PG, Anderson JT and others (2006) Temporal patterns in planktonic food web development in mesocosms with added nutrients and Phaeocystis. Mar Ecol Prog Ser 321:99-121

Paasche A (1973) Silicon and the ecology of marine plankton diatoms. II. Silicate-uptake kinetics in five diatom species. Mar Biol 19:262-269

Parsons TR, Maita Y, Lalli CM (eds) (1984) A manual of chemical and biological methods for seawater analysis. Pergamon Press, Oxford

Porter KG, Feig YS (1980) The use of DAPI for identifying and counting aquatic microflora. Limnol Oceanogr 25:943-948

Editorial responsibility: Hugh MacIntyre, Dauphin Island, Alabama, USA
Price NM, Harrison PJ (1987) Comparison of methods for the analysis of dissolved urea in seawater. Mar Biol 94: 307-317

Riegman R, Noordeloos AAM, Cadee GC (1992) Phaeocystis blooms and eutrophication of the continental coastal zones of the North Sea. Mar Biol 112:479-484

> Ruardij P, Veldhuis MJW, Brussaard CPD (2005) Modeling the bloom dynamics of polymorphic phytoplankter Phaeocystis globosa: impact of grazers and viruses. Harmful Algae 4:941-963

Schoemann V, Becquevort S, Stefels J, Rousseau V, Lancelot C (2005) Phaeocystis blooms in the global ocean and their controlling mechanisms: a review. J Sea Res 53:43-66

See JH, Bronk DA, Lewitus AJ (2006) Uptake of Spartinaderived humic nitrogen by estuarine phytoplankton in nonaxenic and axenic culture. Limnol Oceanogr 51: 2290-2299

Skreslet S (1988) Buoyancy in Phaeocystis pouchetii (Hariot) Lagerheim. J Exp Mar Biol Ecol 119:157-166

Smith DC, Azam F (1992) A simple, economical method for measuring bacterial protein synthesis rates in seawater using ${ }^{3} \mathrm{H}$-leucine. Mar Microb Food Webs 6:107-114

Sunda WG, Graneli E, Gobler CJ (2006) Positive feedback and the development and persistence of ecosystem disruptive algal blooms. J Phycol 42:963-974

Tungaraza C, Rousseau V, Brion N, Lancelot C, Gichuki J, Baeyens W, Goeyens L (2003) Contrasting nitrogen uptake by diatom and Phaeocystis-dominated phytoplankton assemblages in the North Sea. J Exp Mar Biol Ecol 292:19-41

Valderrama JC (1981) The simultaneous analysis of total nitrogen and total phosphorous in natural waters. Mar Chem 10:109-122

Veldhuis MJW, Admiraal W (1987) Influence of phosphate depletion on the growth and colony formation of Phaeocystis pouchetii. Mar Biol 95:47-54

Verity PG, Medlin LK (2003) Observations on colony formation by the cosmopolitan phytoplankton genus Phaeocystis. J Mar Syst 43:153-164

Verity PG, Brussaard CP, Nejstgaard JC, van Leeuwe MA, Lancelot C, Medlin LK (2007a) Current understanding of Phaeocystis ecology and biogeochemistry, and perspectives for future research. Biogeochemistry 83:311-330

Verity PG, Zirbel MJ, Nejstgaard JC (2007b) Formation of very young colonies by Phaeocystis pouchetii from western Norway. Aquat Microb Ecol 47:267-274

- Veuger B, Middelburg JJ, Boschker HTS, Nieuwenhuize J, van Rijswijk P, Rochelle-Newall EJ, Navarro N (2004) Microbial uptake of dissolved organic and inorganic nitrogen in Randers Fjord. Estuar Coast Shelf Sci 61: $507-515$

> Vrede K, Heldal M, Norland S, Bratbak G (2002) Elemental composition $(\mathrm{C}, \mathrm{N}, \mathrm{P})$ and cell volume of exponentially growing and nutrient-limited bacterioplankton. Appl Environ Microbiol 68:2965-2971

Wassmann P, Ratkova T, Reigstad M (2005) The contribution of single and colonial cells of Phaeocystis pouchetii to spring and summer blooms in the northeastern North Atlantic. Harmful Algae 4:823-840

Williams PJleB, Egge JK (1998) The management and behaviour of the mesocosms. Estuar Coast Shelf Sci 46 (Suppl A):3-14

Submitted: November 21, 2006; Accepted: January 29, 2008 Proofs received from author(s): April 25, 2008 